$$
\text { LA-SUB }-96-9
$$

Final Report

\title{
SCREENING LEVEL MODEL FOR ECOLOGICAL RISK ASSESSMENT AT EF-SITE LOS ALAMOS NATIONAL LABORATORY, NEW MEXICO
}

\author{
Prepared for \\ Los Alamos National Laboratory \\ Los Alamos, New Mexico \\ By \\ Colorado State University \\ Center for Ecological Risk Assessment and Management \\ A. W. Alldredge, Ph.D. \\ Department of Fishery and Wildlife Biology \\ T. B. Kirchner, Ph.D. \\ Natural Resource Ecology Laboratory \\ T. McLendon, Ph.D. \\ Department of Rangeland Ecosystem Science \\ E. F. Redente, Ph.D. \\ Department of Rangeland Ecosystem Science
}

RECENED

APR 241996

08.1

\section{DISCLAIMER}

This report was prepared as an account of work sponsored by an agency of the United States Government. Neither the United States Government nor any agency thereof, nor any of their employees, makes any warranty, express or implied, or assumes any legal liability or responsibility for the accuracy, completeness, or usefulness of any information, apparatus, product, or process disclosed, or represents that its use would not infringe privately owned rights. Reference herein to any specific commercial product, process, or service by trade name, trademark, manufacturer, or otherwise does not necessarily constitute or imply its endorsement, recommendation, or favoring by the United States Government or any agency thereof. The views and opinions of authors expressed herein do not necessarily state or reflect those of the United States Government or any agency thereof.

December, 1995

\section{MASTER}




\section{DISCLAMMER}

Portions of this document may be illegible in electronic image products. Images are produced from the best available original document. 


\section{Section 1}

Section 2

Section 3

Section 4
SCREENING LEVEL MODEL FOR ECOLOGICAL EFFECTS OF DEPLETED

URANIUM: SOIL, PLANTS, AND ECOSYSTEM PROCESSES 3

CONCEPTUAL MODEL 3

Soil...

Plants.

Ecological Processes.

LITERATURE REVIEW

Soils

Plants.

Decomposer Subsystem

Ecological Processes...

SCREENING MODEL

Uranium

Information on lead and beryllium for the LANL model.

References

SCREENING LEVEL MODEL FOR DEPLETED URANIUM IN MAMMALS AND BIRDS 11

SPECIES OF IMPORTANCE FOR THE EF SITE SCREENING LEVEL MODEL 12

Species of Economic Importance and Pathway to People:

Threatened \& Endangered Species:

Small Mammal:

Small Bird:

Avian Predator:

Mammalian Predators:

Mammalian Herbivore:

.12

12

. .12

.13

. .13

. .13

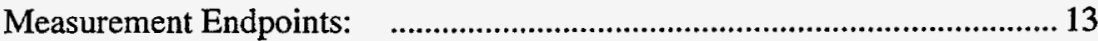

CONCENTRATION RATIOS FOR dU IN BIRDS AND MAMMALS $\quad \ldots 14$

Summary of CR, TC and Uptake Coefficients for Screening Level Model: 15

TOXICITY OF URANIUM IN BIRDS AND MAMMALS …...................16

DATA NEEDS AND FUTURE WORK

LITERATURE CITED $\quad$.......................................................................... 17

Literature Survey on Uranium

21

Phytotoxicity of Depleted Uranium on Three Grasses Characteristic of Different Successional Stages. 35

Abstract

Introduction

Materials and Methods 36

Results 36

Conclusions 37

References: 
Soil

Depleted uranium (dU) in the EF-site originated as debris from expended dU- ordinance. We assume that initial concentrations were highest nearest the detonation point and decreased with distance form the detonation point, with shielding of some areas by berms adjacent to the detonation point (Miera et al. 1980). There has been significant mobility of dU from the soil surface into the soil profile (Miera et al. 1980). Presumably, migration into the soil profile is a result of movement by water and soil mixing by animals and that such migration will continue at rates determined by soil water movement and animal activity.

Plants

For our model, we assume that dU can affect plants in 3 ways. First, it can affect the availability and transport of soil moisture and nutrients. This can be the result of physical or chemical effects of dU on water or nutrients, or it can be the result of effects of $\mathrm{dU}$ on mycorrhizal fungi. Second, dU can function as a contact poison to plant roots, seeds or aboveground tissue. Third, absorbed dU may alter physiological precesses in the plant. Physiological processes most likely to be affected are photosynthesis, respiration, morphogenesis, and enzyme production (Whitehead et al. 1971).

Chemical toxicity of uranium appears to be directly related to its solubility (Brown 1979, Dreesen et al. 1982). Movement in the soil profile at EF-site (Miera et al. 1980) and uranium concentrations in leachate water from mill tailings (Dreesen et al. 1982) suggest that solubility of uranium, its subsequent movement in soil and uptake by microbes and plants is significant. 
There are two methods of entry for $\mathrm{dU}$ into plants; uptake by root systems and deposition on aboveground plant parts. Aboveground deposition occurs via raindrop splash-up and dust deposition.

We also assume that plant species are differentially affected by dU. This fundamental assumption has not been experimentally determined, and we are not aware of any research on the effect of uranium on plants, much less any work on different species. There are a number of studies that measured uranium concentration levels in plants, but we have not found any that measured physiological or ecological effects of uranium on plants. We believe that it is reasonable to assume that different species respond differently to uranium because of differences in morphology, physiology, reproduction, seasonality, growth rate, and tissue chemistry among plant species. Differential uranium uptake and tissue concentration among species (Miera et al. 1980, Dreesen et al. 1987, Wenzel et al. 1987) supports this assumption.

\section{Ecological Processes}

We considered the effect of dU on 2 ecological processes, in addition to plant and animal growth and development. These processes are decomposition/ mineralization and community succession. These processes were selected because they appear to be good indicators of the overall health of the community. Decomposition/mineralization is a measure of the functional condition of the decomposer subsystem and of the nutrient supply to the plant community. Succession is an integrated measure of the overall recovery response of the community following disturbance. If $\mathrm{dU}$ does have an adverse effect on the ecological community, it should result in measurable effects on successional processes or patterns.

Our assumption is that dU can affect decomposition/ mineralization in 2 ways. First, it can alter the availability of soil moisture and nutrients, which would alter the rate of decomposition and mineralization. Second, dU may be toxic or otherwise detrimental to soil organisms. A change in composition or functional response of the decomposer subsystem would also affect the rate, and perhaps the products, of decomposition.

We also assume dU can affect succession in 2 ways. First it can alter the productivity and competitive characteristics of successional species. Since succession is a species replacement process, this would alter the successional pattern. Second, it can affect the availability of soil nutrients which are primary control mechanisms in secondary succession (McLendon and Redente 1991, 1992).

\section{LITERATURE REVIEW}

Soils

Miera et al. (1980) reported dU concentration levels in soils at the EF- site. They found the highest mean concentrations (averaging $4500 \mathrm{ug} \mathrm{U/g}$ soil) in surface soils $(0.0-2.5 \mathrm{~cm}$ ) 
within $10 \mathrm{~m}$ of the detonation point (DP). Uranium concentrations in surface soils beyond $50 \mathrm{~m}$ from DP were generally less than $15 \%$ of those within $10 \mathrm{~m}$. Areas west of DP, out to $150 \mathrm{~m}$, also had high $\mathrm{U}$ concentrations in the surface soil ( $3000 \mathrm{ug} \mathrm{U} / \mathrm{g}$ soil), and surface soils to the south and northeast of DP also exhibited high concentrations (300-1000 ug U/g soil). Background $U$ in area soils were reported to be 0.2 to $1.2 \mathrm{ug} \mathrm{U/g}$ soil (Miera et al. 1980), however, Fresquez (1993) reported values averaging $6.5 \mathrm{ppm}$.

Data from Miera et al. (1980) also indicated significant movement of dU into the soil profile. They reported proportion of total $U$ within soil columns contained in the top $5 \mathrm{~cm}$ of the profile on the basis of distance from DP (Table 1).

TABLE 1. Percent of total uranium in soil column contained in the upper $5 \mathrm{~cm}$, at various depths from the detonation point (DP) at EF-site, Los Alamos National Laboratory, NM. (Data from Miera et al. 1980)

\begin{tabular}{|l|c|c|c|c|c|c|c|c|c|}
\hline Distance $(\mathrm{m})$ from DP: & $\mathbf{0}$ & $\mathbf{1 0}$ & $\mathbf{2 0}$ & 30 & $\mathbf{4 0}$ & $\mathbf{5 0}$ & $\mathbf{1 0 0}$ & $\mathbf{1 5 0}$ & $\mathbf{2 0 0}$ \\
\hline & 68 & 48 & 86 & 71 & 62 & 43 & 64 & 70 & 91 \\
\hline
\end{tabular}

Plants

We are unaware of any data pertaining to ecological or physiological responses of plants to uranium concentration. Whitehead et al. (1971) reported that $U$ incorporated in leaves of the shrub Coprosma australis occurred primarily as a uranium-RNA complex (65\% of incorporated $U$ ), with $44 \%$ occurring in the cell wall fraction, $25 \%$ in chloroplasts, $23 \%$ in mitochondria and nuclei, and $8 \%$ in the supernatant.

There are a number of references to concentrations and concentration ratios (CR). Miera et al. (1980) reported $U$ concentration ratios (plant/soil) of 0.08 for fall vegetation at EF-site, 0.07 for grass, and 0.28 for roots. The higher value for roots was attributed to adherence of $\mathrm{U}$ particles to the outside of root surfaces. Location of contamination would not, however, matter to most consumers feeding on plant roots because they would ingest $U$ that was both in and on root material.

Morishima et al. (1977) reported the following CR (plant/ soil) for food crops in Japan grown in soil with $U$ concentrations averaging $4.2 \mathrm{ppm}$ : root vegetables, 0.001 ; leaf vegetables, 0.0007; potatoes, 0.0004; berries, 0.00013; and grains, 0.00007. Sheppard et al. (1989) determined CR for a number of food crops grown under controlled conditions on a variety of soils. They found mean CR values of 0.030 for grain ( 3 species), 0.084 for stems of grain crops ( 3 species), 0.030 for blueberry stems and 0.80 for blueberry leaves, and 0.042 for potato flesh and 0.079 for potato peel.

Sheppard and Evenden (1992) reported CR of 0.013 to 0.237 for leaves from 20-d old radish plants grown in a greenhouse in a variety of soils. Care was taken to minimize any direct contamination of the leaves from the soil. High CR values were from plants grown in sands and low values were from plants grown in soils high in organic matter. Means of 0.07 occurred on sand loam soils with approximately $3 \%$ organic matter. 
Dreesen et al. (1982) investigated U uptake patterns of plants growing at uranium mill tailings sites. They reported CR (plant/soil) of 0.28 for alkali sacaton (Sporobolus airoides) and 0.16 for four-wing saltbush (Atriplex canescens) grown in contaminated soil (2.5 $\mathrm{ppm} \mathrm{U}$ ) in a greenhouse. Plants growing around a Canyon City, $\mathrm{CO}$, mill were also collected and analyzed. Uranium CR in those plants varied somewhat by plant type and by uranium concentration in the soil. Annuals had CR of 0.025 on background soil (4.2 ppm $\mathrm{U}), 0.104$ on moderately contaminated soil $44 \mathrm{ppm} \mathrm{U}$ ), and 0.176 on more heavily contaminated soil ( $68 \mathrm{ppm} \mathrm{U).} \mathrm{Associated} \mathrm{grasses} \mathrm{had} \mathrm{CR} \mathrm{of} 0.043,0.154$ and 0.529 on the 3 soils respectively.

Ibrahim and Whicker (1988) reported uranium CR for native plants growing at and near a uranium mining and milling operation in Wyoming. Native plants growing in background soils ( $50 \mathrm{mBq}$ U per $\mathrm{g}$ soil) had a mean $\mathrm{CR}$ of 0.088 compared to a mean $\mathrm{CR}$ of 0.809 for plants growing in bare tailings ( $503 \mathrm{mBq} \mathrm{U})$.

Wenzel et al. (1987) reported uranium CR values, by plant part, for ponderosa pine (Pinus ponderosa) trees and associated shrubs growing on a waste burial site at LANL. Uranium concentration of the soil at the site averaged $4.9 \mathrm{ppm} \mathrm{U}$. The shrubs that were sampled were growing at a location with higher $U$ concentration in the soil ( $6.6 \mathrm{ppm})$. Uranium CR's are presented in Table 2.

TABLE 2. Uranium concentration ratios (plant/soil) of tissue from ponderosa pine and shrubs growing on a waste burial site at LANL. (Data from Wenzel et al. 1987)

\begin{tabular}{|c|c|c|c|c|c|c|c|c|}
\hline & $\begin{array}{c}\text { Root } \\
\text { bark }\end{array}$ & $\begin{array}{c}\text { Root } \\
\text { wood }\end{array}$ & $\begin{array}{c}\text { Bole } \\
\text { bark }\end{array}$ & $\begin{array}{c}\text { Bole } \\
\text { wood }\end{array}$ & $\begin{array}{c}\text { Leaves } \\
\text { unbagged }\end{array}$ & $\begin{array}{c}\text { Leaved } \\
\text { bagged }\end{array}$ & $\begin{array}{c}\text { Litter } \\
\text { needles }\end{array}$ & $\begin{array}{c}\text { Litter } \\
\text { other }\end{array}$ \\
\hline Trees & 0.074 & 0.005 & 0.015 & $>0.001$ & 0.014 & na & 0.087 & 0.148 \\
\hline Shrubs & 0.947 & 0.032 & 0.098 & 0.002 & 0.009 & 0.003 & 0.015 & 0.260 \\
\hline
\end{tabular}

Sheppard et al. (1989) and Sheppard and Evenden (1992) indicated that CR of plants is dependent upon the concentration of $U$ in the soil, and data summarized above appears to support this contention.

Decomposer Subsystem

Relatively little information is available in the literature relative to $U$ concentration ratios or effects on decomposers. Sheppard and Evenden (1992) reported uranium CR of 0.08 to 1.53 in earthworms in soils treated with $100 \mathrm{mg} \mathrm{U} / \mathrm{kg}$. The lower values were in soils high in organic matter (18-42\%) and the higher values were in sands with low organic matter content $(0.7$ to $1.0 \%)$. Earthworms in sandy loam soils with 2.5 and $4.2 \%$ organic matter had CR values of 0.34 and 0.46 , respectively. Bohac et al. (1989) reported CR for various species of soil fungi in a forest-steppe ecosystem in Czechoslovakia. Values ranged from 0.003 to 0.6 for $\mathrm{Sr}-90$ and from 0.04 to 1.2 for Cs-137. These more biologically active nuclides would be expected to have higher CR's than would the more biologically inactive uranium. 


\section{Ecological Processes}

To date, few data have been found relative to the effect of $U$ on decomposition or succession. Bloomfield and Kelso (1973) reported that $U$ is mobilized as anions by aerobically decomposing plant matter and that this process in $\mathrm{pH}$ dependent. Two tentative suggestions may also be deduced from the plant concentration data.

First, U concentrations are relatively high in litter (Wenzel et al. 1987), perhaps because of contaminated soil particles associated with litter. Whatever the reason, decomposers not only live in a matrix relatively high in contamination, but they also feed on material that is relatively high in $U$. Unless soil microbes have relatively high tolerances for $U$, this should make the decomposer subsystem more sensitive to $U$ contamination than most segments of the aboveground community.

Second, there appears to be a difference in $U$ concentration ratios between plant lifeforms. Annuals and shrubs may have lower CR's than grasses (Dreesen et al. 1982) and woody portions of trees may have lower CR's than woody portions of shrubs, but the reverse may be true for leaves (Wenzel et al. 1987). Concentration ratios are not sufficient information from which to draw inferences about impacts on decomposers, plant responses and ultimately successional processes. These differences do, however, suggest a successional effect that could be manifest at the herbivore level. The increase in grasses usually associated with mid-seral stages may increase the $U$ intake of grazing animals the associated community.

\section{SCREENING MODEL}

\section{Uranium}

Data we present here appears to be adequate to provide uranium concentration estimates for soil and concentration ratios for plants necessary for development of the screening level model. These estimates are summarized in Table 3, and will be refined for use in the simulation model. Screening level estimates of the effect of dU on plants or on ecological processes are not possible at this point because of lack of data. It is imperative that shortterm experiments be conducted as soon as possible to provide this essential information.

TABLE 3. Initial, realistic screening level estimates of $U$ concentrations (ppm) and concentration ratios (plant/ soil) to be used in the EF-site ecological risk assessment models.

\begin{tabular}{|c|c|c|c|c|}
\hline & \multicolumn{2}{|c|}{ Realistic Estimate } & \multicolumn{2}{c|}{ Screening Level Value } \\
\hline Component & Concentration & CR Value & Concentration & CR Value \\
\hline Plant Overall & 230 & 0.1 & 1300 & 0.3 \\
\hline Seeds & 0.2 & 0.0001 & 5 & 0.001 \\
\hline Berries & 0.4 & 0.0002 & 10 & 0.002 \\
\hline Leaves & 230 & 0.1 & 1350 & 0.3 \\
\hline
\end{tabular}


TABLE 3. Initial, realistic screening level estimates of $U$ concentrations (ppm) and concentration ratios (plant/ soil) to be used in the EF-site ecological risk assessment models.

\begin{tabular}{|c|c|c|c|c|}
\hline & \multicolumn{2}{|c|}{ Realistic Estimate } & \multicolumn{2}{c|}{ Screening Level Value } \\
\hline Component & Concentration & CR Value & Concentration & CR Value \\
\hline Stems & 230 & 0.1 & 1350 & 0.3 \\
\hline Bark & 5 & 0.02 & 230 & 0.1 \\
\hline Roots & 700 & 0.3 & 1800 & 0.4 \\
\hline Litter & 900 & 0.4 & 2700 & 0.4 \\
\hline Soil & 2300 & na & 4500 & na \\
\hline Decomposers & 700 & 0.3 & 1800 & 0.4 \\
\hline
\end{tabular}

Information on lead and beryllium for the LANL model

The following table summarizes the pertinent information in the literature for warning levels, action levels, and transfer coefficients for lead (Table 4). Table 4 is divided into major life forms as opposed to individual species because the literature does not contain information for many of the species at LANL. However the data appears to be consistent enough among species, within a life form, that these transfer coefficients could be applied to LANL species as they relate to the life-form categories in this first table

There is very little information in the literature on warning levels and actions levels for lead contents in plants. Most of the data relates to vegetable crops and would be too conservative for the native species we are working with. The warning and action levels in Table 1 were generated based on phytotoxicity responses of reduced root and shoot growth of seedlings of agronomic plants such as alfalfa and wheat. I have used my best professional judgement to generate warning and action levels for the life-forms in Table 1.

The transfer coefficients presented in Table 4 are ranges that were calculated from studies that used a range of soil lead contents. As lead content in the soil increases, plant tissue content also changes. In general, the transfer coefficient increases as soil content increases, but there are exceptions. Tables 5-7 present actual data showing the relationship between soil lead content and plant tissue content.

TABLE 4. Lead warning levels, action levels, transfer coefficients, and uncertainty factors for major life-forms of concern at LANL

\begin{tabular}{|c|c|c|c|c|c|}
\hline Life-form & $\begin{array}{c}\text { Warning } \\
\text { Level } \\
\mathrm{mg} \mathrm{kg}^{-1}\end{array}$ & $\begin{array}{c}\text { Action } \\
\text { Level } \\
\mathrm{mg} \mathrm{kg}^{-1}\end{array}$ & $\begin{array}{c}\text { Transfer } \\
\text { Coefficient }\end{array}$ & $\begin{array}{c}\text { Uncertainty } \\
\text { Factor }\end{array}$ & References \\
\hline Coniferous trees & 500 & 200 & $0.2-0.7$ & & 4,8 \\
\hline Shrubs & 400 & 150 & $0.1-0.9$ & & $1,2,3,5$ \\
\hline Perennial grasses & 300 & 100 & $0.3-0.5$ & & $1,2,3,5$, \\
\hline Annual grasses & 300 & 100 & $0.07-0.1$ & & $1,2,3,5,6,7$ \\
\hline
\end{tabular}


TABLE 4. Lead warning levels, action levels, transfer coefficients, and uncertainty factors for major life-forms of concern at LANL

\begin{tabular}{|c|c|c|c|c|c|}
\hline Perennial forbs & 300 & 100 & $0.1-0.2$ & & $1,2,3,5,6,7$ \\
\hline Annual forbs & 300 & 100 & $0.06-0.2$ & & $1,2,3,5,6,7$ \\
\hline
\end{tabular}

TABLE 5. Lead content in soil and various plant parts for coniferous tree species (Kovalevskiy, 1979).

\begin{tabular}{|c|c|c|c|c|c|}
\hline $\begin{array}{c}\text { Soil } \\
\mathrm{g} \mathrm{kg}^{-1}\end{array}$ & $\begin{array}{c}\text { Roots } \\
\mathrm{g} \mathrm{kg}\end{array}$ & $\begin{array}{c}\text { Bark } \\
\mathrm{g} \mathrm{kg}^{-1}\end{array}$ & $\begin{array}{c}\text { Needles } \\
\mathrm{g} \mathrm{kg}\end{array}$ & $\begin{array}{c}\text { Twigs } \\
\mathrm{g} \mathrm{kg}^{-1}\end{array}$ & $\begin{array}{c}\text { Wood } \\
\mathrm{g} \mathrm{kg}^{-1}\end{array}$ \\
\hline 0.5 & 0.25 & 0.1 & 0.1 & 0.1 & 0.1 \\
\hline 1 & 1.9 & 1.8 & 0.2 & 0.1 & 0.1 \\
\hline 3 & 6.0 & 5.7 & 2.1 & 0.9 & 0.9 \\
\hline 5 & $10+$ & $10+$ & 3.7 & 0.9 & 0.9 \\
\hline
\end{tabular}

TABLE 6. Lead content in soil and plant tissue of annual and perennial forbs and annual grasses (Lagerwerff et al., 1973; Merry and Tiller, 1978).

\begin{tabular}{|c|c|c|c|}
\hline Soil (ppm) & Annual Forb (ppm) & $\begin{array}{c}\text { Perennial Forb } \\
(\mathrm{ppm})\end{array}$ & $\begin{array}{c}\text { Annual Grass } \\
(\mathrm{ppm})\end{array}$ \\
\hline 25 & 4 & 4 & 2 \\
\hline 50 & 5 & 6 & 4 \\
\hline 100 & 6 & 12 & 7 \\
\hline 150 & 9 & 16 & 13 \\
\hline 200 & 12 & 20 & 22 \\
\hline
\end{tabular}

TABLE 7. Lead content in soil and plant tissue of perennial grasses (Kabata-Pendias and Pendias, 1984).

\begin{tabular}{|c|c|}
\hline Soil $(\mathrm{ppm})$ & Perennial Grasses (ppm) \\
\hline 10 & 5 \\
\hline 20 & 6 \\
\hline 30 & 10 \\
\hline
\end{tabular}

There is very little information in the literature on beryllium. The suggested warning level is $50 \mathrm{mg} \mathrm{g}^{-1}$ in plant tissue and the action level is $10 \mathrm{mg} \mathrm{g}^{-1}$. These numbers come from phytotoxicity studies with agronomic type plants. The transfer coefficient, calculated from just one example in the literature, is 0.20 . This is for a forb (Vaccinium myrtillus) that is considered to be an accumulator of $\mathrm{Be}$. This is a good species to use in the screening model because it gives us a very conservative estimate. 


\section{References}

Wedepohl, K. H. (ed.). 1974. Handbook of Geochemistry. Springer-Verlag, Berlin.

Kabata-Pendias, Alina and Henryk Pendias. 1986. Trace Elements in Soils and Plants. CRC Press, Inc. Boca Raton, FL

Alloway, B. J. 1990. Heavy Metals in Soils. John Wiley \& Sons, Inc. New York.

Klem, Robert B. 1985. Biogeochemical prospecting for gold in the Breckenridge Mining District, Colorado. M. S. Thesis. Colorado State University. Fort Collins, CO.

Lovering, T. G. (ed.). 1976. Lead in the Environment. U.S. Geol. Survey Prof. Pap. 957.

Lagerwerff, J. V., W. H. Armiger, and A. W. Specht. 1973. Uptake of lead by alfalfa corn from soil and air. Soil Sci. 115:455.

Merry, R. H. and K. G. Tiller. 1978. The contamination of pasture by a lead smelter in semi-arid environment. Aust. J. Exp. Agric. Anim. Husb. 18:89.

Kovalevskiy, A. L. 1979. Biogeochemical exploration for mineral deposits. Published for the USDI and NSF. Amerind Publ. Co. Pvt. Ltd. New Delhi. 
For the purposes of our screening level model we assume that toxicity from depleted uranium (dU) will affect birds and mammals before any radiation induced effects become evident (Tracey et al. 1992). Thus, our approach concentrates primarily on ingestion pathways. Using the abstraction of a food web, consumers such as birds and mammals can acquire $\mathrm{dU}$ from ingestion and inhalation. For EF- site, intake of contaminated water is assumed negligible and for most species inhalation would constitute a minor exposure pathway.

First order consumers acquire dU from plants they ingest and soil that may be either directly ingested (Arthur and Alldredge 1979, Arthur and Gates 1988) or from soil attached to ingested plant parts. Similarly, second and higher order consumers acquire dU from animal and/or plant material and soil contamination associated with these food sources. Although most second and higher order consumers likely do not consume soil purposefully, in the case of omnivores such as raccoons and especially bears, they may ingest considerable soil with foods they eat. A bear consuming ants, for example may ingest a good deal of soil. Higher order consumers may also ingest dU associated with the gut contents of their prey. Although our screening level model does allow us to use simple food chains, we will not model all detailed pathways of dU transfer at this level. The use of concentration ratios from source to the target incorporates some gross assumptions about pathways, consumption rates and dU concentration levels.

Inhalation of $\mathrm{dU}$ is likely negligible for almost all birds and mammals with the possible exception of fossorial mammals such as pocket gophers and mice that spend a good bit of their time in the soil matrix. Because of our assumption about the importance of chemical toxicity, inhaled dU would probably not result in deleterious effects on small mammals and the amount of dU deposited in lungs of first order consumers would represent an insignificant transfer to higher order consumers. The broad confidence intervals associated with concentrations of $\mathrm{dU}$ in ingested materials and ingestion rates will more than compensate for any small amounts of dU that could be associated with lung tissue. 
Direct effects of dU on above ground consumers are likely manifest through toxicity. Indirect effects, however, could also impact consumer populations by altering intra- and interspecific interactions such as competition and predation. Results of the screening level model exercise will suggest whether or not these interactions need to be considered at the simulation model level.

\section{SPECIES OF IMPORTANCE FOR THE EF SITE SCREENING LEVEL MODEL}

Although there is a great diversity of species that could be considered in developing a screening level model at EF- site, we have considered the following as being the best representatives.

Species of Economic Importance and Pathway to People:

Elk is likely the best representative because these animals are highly visible, important as a source of revenue from recreational hunting and they are consumed by humans. Also, there are some data available on this first order consumer.

Significance to Stakeholders:

Elk

Raccoon - Native Americans? May not be important at EF Site, but could be important at other sites. Omnivore, thus covers a range of food habits.

Bear - Omnivore that is of significance as a food web integrator, a potential pathway to humans and likely of significance to Native Americans.

Threatened \& Endangered Species:

Do not seem to be of concern at EF-site but will be at others. Thus for EF- site we could develop methodology for small mammal such as meadow jumping mouse, using the deer mouse at EF site. Dose/exposure calculations for individual and extrapolation to population response.

Small Mammal:

Deer mouse - representative, ubiquitous, lives in soil/ atmosphere interface, could be used as endpoint for endangered species such as meadow jumping mouse. Deer mice likely would be representative of a first order consumer that could transfer $\mathrm{dU}$ in the food chain. 


\section{Small Bird:}

American Robin - Located in almost all breeding survey blocks at Los Alamos and is representative for all sites. Forages on ground and therefore likely most exposed to surface contamination. May wish to add violet green swallow then we include aquatic communities.

Avian Predator:

Goshawk would be best because of species sensitivity, but most realistic is likely the Redtailed hawk that is known to use EF-site.

Mammalian Predators:

Bear as representative omnivore and one likely is economically and socially important as well as potentially impacted because of feeding habits.

Bobcat may be important because of the uncertain status of spotted cats in the United States.

Coyotes/foxes could also be considered because they are present at EF-site and, because of their feeding habits, they could accumulate the greatest amount of dU. Both are "bolter" feeders and thus would consume entire small mammals or birds, ingesting pelts and plumage as well as gut contents that could contain dU laden soil.

\section{Mammalian Herbivore:}

Elk and deer mouse

\section{Measurement Endpoints:}

Population reductions, loss of $\mathrm{T} \& \mathrm{E}$ individuals, tissue concentrations.

Most of our results will be extrapolations from the literature based up on uptake and exposure modeling from contaminants in various dietary components (food and soil) Inhalation and direct ingestion of soil from grooming or contaminated pelts will be important in small mammals and predators. Beyond the screening level model, it may be necessary to also consider inhalation of contaminants by birds during dusting and ingestion of grit by some avian species. 


\section{CONCENTRATION RATIOS FOR dU IN BIRDS AND MAMMALS}

Atmospheric inputs of dU into the system at EF-site are essentially negligible, thus depleted uranium may enter the animal food chains by, consumer ingestion of dU that is in plants, ingestion dU that is on plants and direct soil ingestion. Plant uptake of dU and resuspension of contaminated surface soil to plant surfaces thus influence concentrations of dU associated with plants. For second and higher order consumers, the problem is conceptually the same with the mode of entry being dU that is in or on food materials. Soil ingestion may assume lesser importance in higher order consumers, but dU associated with pelage, plumage and gut contents may also enter these organisms. In our screening level model, the use of concentration ratios (CR) which we define as the amount of dU in the organism divided by the amount of $\mathrm{dU}$ in the source (generally the soil), reflects all possible modes of entry.

There is a paucity of concentration ratios published in the peer reviewed literature, and limited data from which these ratios can be calculated. In some instances it may be necessary to approximate the CR for $\mathrm{dU}$ from data for other heavy metals. Fortunately, there are some site specific data available from Miera et al. (1980). Establishing concentration ratios for ecosystem compartments in arid systems would provide valuable information for ecological risk assessments.

Specifically for EF-site, Miera et al. (1980) report soil to small mammal concentration ratios of 10-3 to 10-4, although they also report gastrointestinal contents from small mammals with mean uranium levels greater than $10 \%$ of soil concentrations. Data presented in this manuscript provide enough information to calculate a crude probability density function for CR's in small mammals.

The NCRP (1989) reports concentration ratios for fresh vegetables and dry forage and transfer coefficients (TC, concentration in product divided by daily intake) for milk and beef. Applicable to our screening level model would be the TC for beef which they report as $1 \times 10-2$ with no confidence estimates reported. Although this transfer coefficient is developed to predict the concentration of uranium in humans consuming beef, it should be a very conservative estimate for a carnivore consuming a uranium contaminated food source. For lack of better information, this coefficient will be used to estimate concentrations in predatory mammals in our screening level model.

Using data presented by Robinson et al. (1984) we calculated a CR for uranium in Japanese quail. Those authors reported a concentration in food (gamebird chow and oyster shell) of $3.27 \mathrm{ug} / \mathrm{g}$, a concentration in quail of 3.49 to $3.55 \mathrm{ug}$ and an average quail body weight of $135 \mathrm{~g}$. Thus a CR becomes $0.026 / 3.27$ which equals 0.008 . This CR (Carcass to Food) can be used as an approximation for granivorous birds and in lieu of better information will be used in our model for robins. For lack of better data, we must also use this factor for predatory birds although we suspect that it is not accurate. The reason that we elected to use this value for birds rather than attempting to approximate from predatory mammals is two-fold. First there are no mammalian data. Second, calcium metabolism in birds differs from that of mammals because estrogens in birds stimulates growth of medul- 
lary bone (Kupsh and Robinson 1989). Thus the fraction of uranium deposited in bones of birds also increases relative to the fraction deposited in mammals (Robinson et al. 1986).

Gilbert et al. (1988) working with plutonium in the arid systems of Nevada report CR for cattle and kangaroo rats. Their data are from 3 sites and they report a CR for carcass/vegetation and one for carcass to soil. For kangaroo rats carcass to vegetation ratios ranged from 0.024 to 0.042 and carcass to soil values were 0.00009 to 0.0013 . For cattle their ratios were 0.00078 and 0.00012 respectively (Gilbert et al. 1988, page 882 ). These data may be used to approximate $\mathrm{CR}$ for dU in deer mice and elk. Concentration ratios for plutonium in small mammals in a semi-arid grassland system in northcentral Colorado were reported to be $7.77 \times 10-3$ with a $95 \%$ confidence interval of $2.09 \times 10-3-1.3 \times 10-2$ for mammals in a contaminated area and $2.14 \times 10-1$, 95\% confidence interval $-4.16 \times 10-2$ 4.7 x 10-1 (Little 1976).

Tracey et al. (1992) published uptake coefficients (not CR) for uranium in drinking water of rabbits and rats. Those investigators report a gut uptake factor (percent) of $0.063+$ $0.007 \%$ for rabbits and $0.06+0.01$ for rats (Tracey et al 1992, Table 6, page 70). Earlier work reported similar gut absorption factors for rats: Hamilton $(1948)<0.05 \%$, Sullivan (1980) $0.61+0.009 \%$ for gavaged rats fed ad libitum, and Sullivan et al. (1986) $0.17 \%$ for fasting rats. Uptake of uranium appears to be higher in gavaged, fasted rats because La Touche et al. (1987) reported gut absorption values of 0.6 to $2.8 \%$ using those experimental conditions.

\section{Summary of CR, TC and Uptake Coefficients for Screening Level Model:}

CR for elk: Data from Nevada plutonium studies on cattle feeding on native ranges. Carcass to vegetation: 0.00078 ; Carcass to soil: 0.00012

CR for deer mice: Data from EF-site suggesting CR's of 10- 3 to 10-4 for deer mice and pocket gophers. Data from Nevada plutonium studies on kangaroo rats feeding on native ranges. Carcass to vegetation: 0.024 to 0.042 . Carcass to soil: 0.00009 to 0.0013 .

CR for all birds (robins and hawks): Data extrapolated from work on captive Japanese quail fed commercial rations. Carcass to food: 0.008 .

TC for predatory mammals: Estimate from NCRP $1989.0 .01 \mathrm{~d} / \mathrm{kg}$

Uptake Coefficients for mice: Data from rats and rabbits either gavages or receiving intake from drinking water. $.06+0.007 \%$ GI uptake of uranium from water for rats is reported to range from 0.06 to $0.17 \%$. 


\section{TOXICITY OF URANIUM IN BIRDS AND MAMMALS}

The threshold for toxic damage for uranium in mammals is reported as low as $0.1 \mathrm{mg}$ uranium per kilogram body weight entering the bloodstream (Yuile 1973). Thus, chemical toxicity of uranium would be very pronounced before any radiological effects of uranium were manifest (Tracey et al. 1992). This would be especially true for depleted uranium. In our screening level model we concern ourselves only with chemical toxicity of uranium.

Yuile (1973 page 168) cites work indicating that approximate lethal doses of uranyl nitrate hexahydrate administered intravenously were: rabbits $0.1 \mathrm{mg} \mathrm{U} / \mathrm{kg}$; guinea pigs, $0.3 \mathrm{mg}$ $\mathrm{U} / \mathrm{kg}$; rats, $1.0 \mathrm{mg} \mathrm{U} / \mathrm{kg}$; mice 10 to $20 \mathrm{mg} \mathrm{U} / \mathrm{kg}$.

Domingo et al. (1989a) reported maternal toxicity for uranyl acetate dihydrate in mice at dose levels of $5,10,25$ and $50 \mathrm{mg} / \mathrm{kg}$ per day. The NOEL (no observable effect level) for fetotoxicity was below $5 \mathrm{mg} / \mathrm{kg} / \mathrm{day}$ in their study. The did report, however, that there was no embryolethality at any dosage level in their study. In another study, Domingo et al. (1989b) evaluated the perinatal and postnatal effects of uranium on mice administering uranyl acetate dihydrate at dosages of $0,0.05,0.5,5$ and $50 \mathrm{mg} / \mathrm{kg}$ from day 13 or pregnancy until litters were weaned 21 days post-parturition. No effects in sex ratios, mean litter size, pup body weight or pup body length was observed at the lower dose levels. At the $50 \mathrm{mg} \mathrm{U} / \mathrm{kg}$ body weight dose level, however, there were significant decreases in mean litter size and viability of litters. These authors conclude that for developing mice pups, the NOEL for health hazards caused by uranium was $5 \mathrm{mg} / \mathrm{kg} /$ day. In both these studies (Domingo et al. 1989a and 1989b) animals were dosed with oral gavage.

Ortega et al. (1989) evaluated the oral toxicity of uranium in a 4-week drinking water study in rats. Their dose levels were $2,4,8$, and $16 \mathrm{mg} / \mathrm{kg} /$ day and they reported seeing no consistent compound- related effects in any of the parameters they measured.

Because Yuile (1973) presents data to indicate that mice may be more tolerant of uranium than other small mammals studies, it would seem prudent to use a level below $5 \mathrm{mg} \mathrm{U} / \mathrm{kg}$ body weight/day as a NOEL for a screening level model evaluation. Animals at EF Site are obtaining uranium from ingestion of contaminated soil and food rather than being gavaged with liquid. We assume that assimilation of uranium from food and soil would probably be less than for liquid gavage. Thus a value of 2 to $5 \mathrm{mg} \mathrm{U} / \mathrm{kg}$ body weight/ day might well represent a NOEL estimate for our purposes.

Ortega et al. (1989) exposed rats to uranyl acetate dihydrate in drinking water at levels of $0,2,4,8$, ad $16 \mathrm{mg} / \mathrm{kg}$ body weight/day continuously for 4 weeks. These authors reported no deaths, weight loss or reduction in food and water intake at any of these dose levels. The only abnormality these investigators report is a congestion in the liver for animals at the highest dose level. 


\section{DATA NEEDS AND FUTURE WORK}

From our search of the scientific literature, it appears that there is limited information on concentration ratios for uranium in consumers, and almost no information for these organisms in the natural environment. We will continue our search for better estimates of concentration ratios and uptake coefficients. We also suggest that studies be designed and initiated to obtain better estimates of these important parameters.

Application of toxicity data from laboratory experiments to field situations may be questionable. Dose levels that do not produce measurable effects in the laboratory may be harmful to animals in the wild by reducing their competitive capabilities or making them more susceptible to predation. For the purposes of our modeling exercise, conservative use of laboratory toxicity data may be adequate.

\section{LITERATURE CITED}

Arthur, W. J. III. and A. W. Alldredge. 1979. Soil ingestion by mule deer in northcentral Colorado. J. Range Manage. 32:67-70

Arthur, W. J. III. and R. J. Gates. 1988. Trace element intake via soil ingestion in pronghorns and in black-tailed jackrabbits. J. Range Manage. 41:162-166.

Bohac, J., D. A. Krivolutskii, and T. B. Antovona. 1989. The role of fungi in the biogeneous migration of elements and in the accumulation of radionuclides. Agriculture, Ecosystems and Environment. 28:31- 34

Bloomfield, C. and W. I. Kelso. 1973. The mobilization and fixation of molybdenum, vanadium and uranium by decomposing plant matter. J. Soil Sci. 24:368-379.

Brown, M. L. 1979. Plant uptake parameters for Am-121, Pu- 239, Cs- 137 and uranium. MS Thesis. Colorado State University, Ft. Collins.

Domingo. J. L., J. L. Paternain, J. M. Llobet and J. Corbella. 1989a. The developmental toxicity of uranium in mice. Toxicology 55:143-152.

Domingo, J. L., A. Ortega, J. L. Paternain and J. Corbella. 1989b. Evaluation of the perinatal and postnatal effects of uranium in mice upon oral administration. Arch. of Env. Health. 44:395-398.

Dreesen, D. R., J. M. Williams, M. L. Marple, E.S. Gladney and D. R. Perrin. 1982. Mobility and bioavailability of uranium mill tailings contaminants. Env. Sci and Tech. 16:702-709.

Fresquez, P. R. 1993. Environmental restoration interim action (ERIA) reconnaissance survey over areas where wastewater collection lines are planned to be installed in route the new sanitary wastewater systems consolidation (SWSC) treatment plant 
at TA-46. Memorandum. Environmental Protection Group (EM- 8). Los alamos National Laboratory, Los Alamos, NM.

Gilbert, R. O., J. H. Shinn, E. H. Essington, T. Tamura, E. M. Romney, K. S. Moor and T. P. O'Farrel. 1988. Radionuclide transport from soil to air, native vegetation, kangaroo rats and grazing cattle on the Nevada Test Site. Health Phys. 55:869-887.

Hamilton, J. G. 1948. The metabolic properties of the fission products of actinide elements. Rev. Mod. Physics 40:718-728. (As cited in Tracey et al. 1992)

Ibrahim, S. W. and F. W. Whicker. 1988. Comparative uptake of $U$ and Th by native plants at a $U$ production site. Health Phys. 54:413-419.

Kupsh, C. C. and G. A. Robinson. 1989. Linearity of the accumulation of various dosages of uranium in the major organs of mature male Japanese quail. Effect of various doses of estradiol-17B. Comp. Biochem. Physiol. 92C:55-59.

La Touche, Y. D., D. L. Willis, O. I. Dawydiak, 1987. Absorption and biokinetics of U in rats following an oral administration of uranyl nitrate solution. Health Phys. 53:147-162.

Little, C. A. 1976. Plutonium in a grassland ecosystem. PhD. Thesis. Colorado State University, Ft. Collins. 170pp.

Mclendon, T. and E. F. Redente. 1991. Nitrogen and phosphorus effects on secondary succession dynamics on a semiarid sagebrush site. Ecology. 72:2016-2024.

1992. Effects of nitrogen limitation on species replacement dynamics during early secondary succession on a semiarid sagebrush site. Oecologia. 91:312-317.

Miera, F. R. Jr., W. C. Hanson, E. S. Gladney and P. Jose. 1980. Mobility of elevated levels of uranium in the environment. Pages 681-699 in T. F. Gesell and W. M. Lowder (eds.) Natural Radiation Environment III, Vol. 1. DOE Symposium Series 51 (CONF-78042) NTIS, Springfield, VA.

Morishima, H. T. Koga, H. Kawai, Y. Honda and K. Katsurayama. 1977. Studies on the movement and distribution of uranium in the environment- distribution of uranium in agricultural products. J. Rad Res. 18:139-150.

NCRP. 1989. Screening techniques for determining compliance with environmental standards. Releases of radionuclides to the Atmosphere. National Council On Radiation Protection and Measurements Commentary No. 3.

Robinson, G. A., C. C. Kupsh, D. C. Wasnidge, F. Floto and B. L. Robinson. 1986. Increased deposition of uranium in the bones of vitellogenic male Japanese quail. Effect of estradiol-17B on the distribution of U(VI), Th(IV), Gd(III) and $\mathrm{Ca}(\mathrm{II})$. Poultry Sci. 65:1178-1183. 
Robinson, G. A., D. C. Wasnidge and F. Floto. 1984. A comparison of the distributions of the actinides uranium and thorium and the lanthanide gadolinium in the tissues and eggs of Japanese quail: Concentrations of uranium in feeds and foods. Poultry Sci. 63:883-891.

Sheppard, S. C., W. G. Evenden and R. J. Pollock. 1989. Uptake of natural radionuclides by field and garden crops. Can. J. Soil. Sci. 69:751- 767.

Sheppard, S. C. and W. G. Evenden. 1992. Bioavailability indices for uranium: effect of concentration in eleven soils. Arch. Env. Cont. and Tox. 23:117-124.

Sullivan, M. F. 1980. Absorption of actinide elements from the gastrointestinal tract of rats, guinea pigs and dogs. Health Phys. 38:159-171.

Sullivan, M. F., P.S. Ruemmler, J. L. Ryan and R. L. Buschbom. 1986. Influence of oxidizing or reducing agents on gastrointestinal absorption of $\mathrm{U}, \mathrm{Pu}, \mathrm{Am}, \mathrm{Cm}$, and $\mathrm{Pm}$ by rats. Health Phys. 50:223-232.

Tracey, B. L., J. M. Quinn, J. Lahey, A. P. Gilman, K. Mancuso, A. P. Yagminas and d. C. Villenueve. 1992. Absorption and retention of uranium from drinking water by rats and rabbits. Health Phys. 62:65-73.

Wenzel, W. J., T. S. Foxx, A. F. Gallegos, G. Tierney and J. C. Rodgers. 1987. Cesium137, plutonium-239/240, total uranium and scandium in trees and shrubs growing in transuranic waste at Area B. LA-11126-MS. Los Alamos National Laboratory, Los Alamos, NM. 62 pp.

Whitehead, N. E., R. R. Brooks and P. J. Peterson. 1971. The nature of uranium occurrence $\mathrm{n}$ the leaves of Coprosma australis (A. Rich) Robinson. Austrl. J. Bio. Sci. 26:6773.

Yuile, C. L. 1973. Animal Experiments. Pages 165-193. In: Hodge, H.C., J. N. Stannard and J. B. Hursh, eds. Uranium, plutonium, transplutonic elements. Handbook of experimental pharmacology. Vol. 36. Springer- Verlag, Berlin. 995pp. 


\title{
Uranium
}

\author{
Mike Meyer
}

Below is an annotated list of references for uranium in the environment.

Eds. Voegtlin and Hodge. (1949-1953) McGraw-Hill Book Co., Inc.

Complete survey of methodology, analytical chemistry and findings of the Manhattan Project and Atomic Energy Commission research on uranium. Different routes of exposure, uptake/excretion rates, mechanisms of actions, and pathology of toxicity are all discussed for several mammals species, including some human exposure. Acute and chronic exposures are covered.

Ed. Tannenbaum. (1951) McGraw-Hill Book Co., Inc.

Summary of work performed by the Manhattan Project and the Atomic Energy Commission on toxicology of uranium. Papers dealing with uptake, tissue distribution, lethality, biochemistry, pathology and pharmacokinetics of uranium in laboratory species are presented. Overall, a fairly exhaustive analysis of uranium toxicity is given.

Cannon. Am J Science (1952) 250:735.

Extensive study with a very good review of much early work on uranium effects in plants. Beneficial effects are observed up to concentrations of less than $5 \mathrm{ppm}$ for plants, and up to $24 \mathrm{ppm}$ for bacteria. At higher concentrations, several indicators of toxicity become apparent. Evidence that $U$ is absorbed by root, and stored in the cell nuclei of the meristem, resulting in chromatin damage. Other effects include growth depression, yellowing of leaves, and reddening of the stems and seeds. Also given is a list of U-tolerant flora. Measurements of leaves of plants growing in ore had $U$ levels of up to $100 \mathrm{ppm}$.

Chapman and Hammons. Health Phys (1963) 9:79-81.

Early work examining if there are differences in uptake and excretion between ruminants and non-ruminants. Conclusions that cattle were very similar to small laboratory mammals.. 
Osburn. Health Phys (1965) 11:1275-1295.

Review of the then 'state-of-the-art' knowledge of the location, movement, and effects of naturally occurring radioisotopes. Uranium and its decay product are the most discussed of these. A decent review of the pathways available for nuclide transfer within an ecosystem.

Prister (Rus-trans.) A/AC.82/G/L.1298 (yr?)

Relatively early work on the uptake of $U$ by agricultural plants. Measures of transfer to farm animals was also assessed. Transfer to cattle milk and hen eggs was emphasized. Some calculations for excretion were also performed. The ultimate goal was assessment of risk to human consumption of products.

D'souza and Mistry. Rad Botany (1970) 10:293.

Nutrient culture experiments with red kidney beans to quantitatively compare uptake of different nuclides. Th, $\mathrm{Pb}$, and Po predominately accumulated in the roots. Ra showed much less root accumulation, but had a 50 to 200 times greater translocation to the shoots. The amounts accumulated were much higher from nutrient solutions than from soil, thus suggesting bioavailability issues.

Athalye and Mistry. Rad Botany (1972) 12:287.

Comparison of the two radionuclides in regards to movement within the plant, and between the plant and the soil. Red kidney bean plants were used for the various studies.

. Hanson. LA-5559 (1974).

Discussion of DU properties and processing. Suggestion that chemical toxicity is of greater ecological concern than is radiation, and that DU is less toxic than natural uranium. A review of early work on natural uranium effects on plants and on aquatic systems is given. Lastly, suggestions for needed future work are made. Hanson LA-5654 (1974).

Discussion of the production and distribution of aerosols and particles of DU penetrators when fired against a solid object. No mention of ecological concerns.

Tuovinen and Kelly. Arch Microbiol (1974) 95:153-179.

Addition of 5-100 mM uranyl sulphate caused cessation of $\mathrm{CO}_{2}$ fixation, loss of cell viability, and a decrease in ferrous iron oxidation. Tolerance was achievable in cultures if gradually exposed to increasing levels of uranium. Uncoupling of $\mathrm{CO}_{2}$ fixation was likely due to interference of energy metabolism. Analysis of the kinetics of uranium inhibition of iron oxidation indicated mixed and noncompetitive mechanisms.

Hanson and Miera. LA-6269 (1976).

Description of EF-site contamination and measurement of $U$ levels in soil, vegetation, and small mammals. Mammal analysis was performed on pelt, GI, and 
carcass. Pocket gophers, deer mice, and harvest mice were tested. In all cases, GI tracts had the highest concentration. Comparisons between control and EF-site mammals were made. No clear conclusions could be made. Observation that there is a difference ion plant tolerance to uranium was made. Finally, a short description of soil invertebrate populations in the control and impacted sites was offered.

Hanson and Miera. LA-6742/AFATL-TR-77-35 (1977).

Continuation of the above work with particular emphasis on greater definition of $U$ distribution at E-F site, and on macrofauna work. Though not statistically significant, differences in both number and diversity of invertebrates was observed between E-F and control sites. This was suggestive of a community level reduction at the E-F site.

Vavilov Sov J Ecol (1977) 8:496.

The deep fill method followed by revegetation of the site was analyzed. Results suggested early success, however, after 8 to 10 years $\mathrm{Ra}$ had migrated back to the surface due to vegetative transport. $U$ transport was much lower.

Murray and Moffett. J Soil Water Conserv (1977) 32:171.

Comparison of several different plants for restoration of tailings site. Comparison of long-term viability, rate of ground covering, and yield were made. No supplemental soil was provided, though the existing material was enhanced by the addition of lime and fertilizers.

Koeppe. Sci Total Environ (1977) 7:197.

Literature review and synopsis of what is currently known. Conclusion that $\mathrm{Cd}$ is a greater environmental danger than $\mathrm{Pb}$, though it is less widespread and is found in lower concentrations.

Dreesen. LASL-77-37 (1978).

Mini-review discussing environmental pathways of concern in terms of $U$ tailings. No references or experimental data offered.

Hanson and Miera. LA-7162/AFATL-TR-78-8 (1978)

Further continuation of the above two studies. Additional analysis of uranium deposition and spatial variation at E-F site was made. A more in-depth survey of deer mice and pocket gophers was also performed. Deer mice contained higher $U$ levels than the gophers. Routes of uptake are discussed. Lastly, a more conclusive answer was offered in terms of macrofauna differences between control and impacted sites. The authors concluded that differences observed in previous years could not be accounted for on the basis of $U$ concentrations.

Garten. Environ Res (1978) 17:437-52.

Theoretical paper concerned with the factors important to the modeling of the fate of atmospherically deposited radionuclides. Emphasis is on the ultimate transfer of 
nuclides to humans. Possible transfer pathways shown and estimates given for transfer coefficients.

Titaeva . Sov J Ecol (1978) 9:328.

Analysis of soil and plant concentrations at different sites in the former USSR.

Whicker in Sym on U Mill Tailings Mgmt (1978) CSU.

Broad review of factors influencing the long-term stability of chemicals and radionuclides at tailing sites. Factors analyzed in terms of land-cover technology include control of erosion, and the transfer to biota. Some data given in terms of plant and animal CR's from the soil.

Stoetzel, Waite, Gilchrist. PNL-APG 373 (1979).

Internal paper documenting distribution of fired munitions in the environment, and accumulation by the biota during wet and dry times of the year.

Zvyagintsev and Andreeva. Moscow U. Soil Sci Bull (1979) 33:25.

Technique for improving the number of microorganisms that can be analyzed.

Schreckhise and Cline. Health Phys (1979) 38:817.

Alfalfa, barley, peas, and cheatgrass were studied for uptake of the listed nuclides. Only above ground components were analyzed. Legume uptake was $10 \mathrm{X}$ that of grass. Seed concentration was much lower than other plant parts. Only Np showed uptake dependent on soil concentration. Uptake was as follows: $\mathrm{Np}>\mathrm{Cm}=\mathrm{Am}>\mathrm{Pu}$.

Miera in Natural Radiation III, Vol 1. eds. Gesell and Lowder (1980) NTIS- DOE/Conf780422.

Summary of the 3-yr study of the E-F site work by Miera and Hanson. Figures of estimated isopleths of uranium distribution on the site. Plant/soil and animal tissue/ soil CR's are given. Lastly, there is a short discussion of the mobility and physical transport of DU at the E-F site.

Garten. Health Phys (1980) 39:332.

Seasonal variation of uptake was analyzed in boxelder trees. For U-234, Cr's ranged from 0.70 to 13.1 over the May to September period, and for U-238, the ratios went from 0.70 to 13.1 .

Rayno, Momeni, Sabau. Sym on U Mill Tailings Mngt. CSU-1980.

Concentrations of U-238, U-234, Ra, and PB were determined for 8 forage grasses and shrubs of NM. Ratios of root activity to shoot activity varied from 0.3 to 38.0. Concentration ratios varied from 0.01 to 0.69 .

Sullivan. Health Phys (1980) 38:159-171. 
Paper comparing transport across the GI tract for 'soluble' nitrate and 'insoluble' oxide compounds of a dozed actinide isotopes, including U-232 and U-233. Factors -influencing absorption were determined to be particle size, compound form, and mass of compound administered.

Sullivan. Health Phys (1980) 38:173-185.

Comparison of uptake of a dozen actinides by neonates versus adults. A 20 to 100 fold increase in uptake for Pu-238 was observed in neonates. Absorption was modified by particle size, valence, chemical form, and animal age.

Garten, Bondietti, Walker. J Environ Qual (1981) 10(2):207.

Looked at uptake by fescue, grasshoppers, and small mammals. Compared U/Pu and $\mathrm{Th} / \mathrm{Pu}$ ratios in soil and biota. U/Pu ratios in small mammals were significantly greater that in soil. No difference for Th/Pu in animals versus soil, but was different for fescue (greater). Pattern of accumulation was $U>T h=P u$.

White, Hakonson, Ahlquist. J Environ Qual (1981) 10(3):294-299.

Field study to get at factors influencing $\mathrm{Pu}$ and $\mathrm{Cs}$ contamination of squash and beans. Cr's are given, with the highest being 0.255 for Cs. Manure reduced uptake by 30 to $50 \%$. A large percentage of the contamination was surficial, likely due to wind and water re-suspension from the soil.

Harrispon and Stather. Rad Res (1981) 88:47-55.

Study looking at the uptake of uranyl nitrate and $U$ dioxide after intravenous and intragastrically administered solutions. Absorption factors are obtained and compared to ICRP values for humans.

Dreesen Environ Sci Tech (1982) 16(10):702-709.

Factors related to mobility of various heavy metals and contaminants associated with $\mathrm{U}$ mining are discussed. More of a geochemical paper than ecological.

Netten and Morley. Intern J Environ Stud (1982) 19:43.

Study in British Columbia in an area naturally high in $\mathrm{U}$ and Mo. CR's for U ranged from 0.020 to 0.433 . Mo ratios ranged from 3.0 to 5.5. Different mechanisms of uptake for the two metals are presumed.

Sullivan and Gorham. Health Phys (1982) 43(4): 509-519.

Further work looking at factors influencing the enhanced uptake of actinides by neonates in comparison to adults. Important factors include: mass of actinide, oxidation state, and solubility.

Mahon. Bull Environ Contam Toxicol (1982) 29:697.

Interested in bioconcentration of nuclides and food chain transfer for $\mathrm{U}, \mathrm{Pb}, \mathrm{Po}$ and $\mathrm{Ra}$. Looked at the following chains: sediment-algae-plankton-benthos-fish, 
browse veg.-deer, and veg.-small mammals-carnivorous birds. Paper is data poor and statistically weak. Some BAF's calculated and some general conclusion reached. General observation that for each trophic level, there is a drop of one order of magnitude in the body burden.

Mahon and Mathewes. Bull Environ Contam Toxicol (1983) 30:575.

Looked at bioaccumulation of nuclides in water-lily, and the effect of seasonal changes on this process. Significant variation was observed over seasons, with the mechanism likely being changes in plant physiology. Conclusions included that aquatic macrophytes could constitute an important link in the overall transport of radionuclides and metals in water bodies. Suggestion that food chain transfer to herbivores mammals (esp moose) may be important.

Haseltine and Sileo. J Wildl Manage (1983) 47(4):1124-1129.

Dietary doses of $0,25,100,400,1600$ ppm tested on ducks. Diet was for 6 weeks. No kidney or lever effects were observed. Low toxicity explained as possible species differences. Further work needed as to fate in the environment and possible indirect effects.

Whicker. Rad Res (1983) 94:135-150.

Review of pathways of radionuclides through the environment. Observations given for $\mathrm{Cs}, \mathrm{Sr}, \mathrm{I}, \mathrm{H}$ and $\mathrm{Pu}$. Properties of nuclides, organisms, and ecosystems are considered. Bulman. pages 105-113 in Ecological aspects of Radionuclide Release. ed: Coughtrey (1983) Blackwell Scientific Pubs.

Discussion of the factors involved in nuclide speciation, and the resulting changes in bioavailability.

Norberg and Molin. Water Res (1983) 17(10):1333.

Toxic effects of heavy metals on the bacteria Z. ramigera studied. Metrics analyzed included lag phase length, and growth rate. Order of toxicity was $\mathrm{Cd}=\mathrm{Zn}>\mathrm{Co}>\mathrm{UO}_{2}$. The bacteria responded to $U$ differently than to the other metals. Lag phase was not correlated with U concentrations. Inhibition of growth occurred at $1000 \mathrm{ppm}$.

Koul, Kaul, Chadderton. Env Exp Bot (1983) 23(4):379.

Used fission track technique to look at uptake of $U$ in an edible cucurbit. Concentration was highest in roots, and less so in stem, flower and leaf systems. Positive correlation between uptake and the cytological abnormality of altered chromosome number. Other effects included altered germination times (enhanced), different plant shape/growth, leaf deformation, different reproduction (decreased). uranium oxide concentrations of $0.35,1.5$, and $2.5 \mathrm{uCi} / \mathrm{l}(\mathrm{PPM})$ studied.

Szefer, Falandysz. Sci Total Environ (1983) 29:277-280.

Paper documents levels of contamination in different tissues of ducks living in Gdansk bay, Poland. No transfer factors or indication of source of contaminants given. 
Mahon and Mathewes. Can J Soil Sci. (1983) 63:281.

Accumulation of $\mathrm{U}, \mathrm{Ra}, \mathrm{Pb}$, and $\mathrm{Po}$ was analyzed in 15 species found in British Columbia. Concentration ratios for $U$ ranged from 0.002 to 0.315 . Some seasonal variability was observed. Soil effects were mentioned.

Murthy, Weinberger, Measures. Bull Environ Toxicol (1984) 32:580.

Effects on germination and growth of soybean was studied using two concentrations of $\mathrm{U}, 0.42$ and $42 \mathrm{ug} / \mathrm{mL}$. Germination was not found to be effected, whereas growth was significantly depressed. Uptake increased with increasing soil concentration, and was preferentially located in the roots. Toxic symptoms were also observed, including: chlorosis, early leaf abscission, reduction in root growth, and at the higher concentration, widespread tissue necrosis.

Sheppard, Sheppard, Thibault. J Environ Qual (1984) 13(3):357.

$\mathrm{U}$ and $\mathrm{Cr}$ uptake, redistribution and effect on growth were studied using field lysimeters. Two soil types (sand and loam) were cross tested with two plants, alfalfa, and Swiss chard. No growth effects were observed at the tested concentrations of 50 and $100 \mathrm{mg} / \mathrm{kg} \mathrm{U}$ or 20 and $50 \mathrm{mg} / \mathrm{kg} \mathrm{Cr}$. Uptake of Cr was dependent on plant and soil type, but was independent of amount and depth of contaminant placement. Uptake of $U$ varied with plant and soil type, as well as amount of $U$ present and depth of placement. It was concluded that transpiration of water and/or root uptake was a substantial factor in translocation of $U$ in sandy soil.

Boileau, Nieboer, Richardson. Can J Bot (1984) 63:384.

Lichens as biological markers. Comparison of different forms of uranyl ion. Uptake was different for the different speciation as follows:

cation $>>$ neutral $>>$ anion

Dreesen and Cokal. Water Soil Air Poll (1984) 22:85-93.

A method paper demonstrating a soil-free technique for assessing plant uptake of contaminants and trace metals. Overall goal was to estimate bioavailability of compounds/elements to various plants. U Bioavailability differed with plant species.

Poston, Hanf, Simmons. Water Soil Air Poll (1984) 22:289-298.

Standardized acute and chronic LC50 tests with uranium and daphnia. Acute toxicity was set at $6 \mathrm{mg} / \mathrm{L}$, though toxicity diminished with increasing alkalinity and hardness of water.

Sheppard and Sheppard. Health Phys (1985) 48(4):494-500.

Discussion of the assumptions involved in the $C R$ approach to plant uptake. The linearity of uptake assumption was tested through comparison of 2 natural sites and a controlled experiment. Conclusions were that above $20 \mathrm{ppm} U$ in soil, CR approach was valid; lower concentrations demonstrated hyperbolic curves and 
hence may not be accurate.

Dunn, Ek, Byman. IAEA-TECDOC-327 (1985).

Technical publication concerned with using plants as an indicator of uranium deposits. Extensive reference list with some papers concerning uranium effects on plants and bacteria.

Sheppard, Thibault, Sheppard. Water Soil Air Poll (1985) 26:85-94.

Paper analyzing observed depressed growth of Scots pine near a nuclear waste site. Phytotoxicity explained by chemical, not radiation effects. Authors conclude that phytotoxic soil concentration for $U$ is $>100 \mathrm{ppm}$.

Rogers and Li. Bull Environ Contam Toxicol (1985) 34:858-865.

Paper extolling the virtues of the dehydrogenase test as a rapid and precise method fro assessing toxicity of compounds on soil microbes. Did not test U effects.

Wrenn Health Phys (1985) 48(5):601.

Human directed paper aimed at getting at safe levels of U. Kidney is the organ of earliest toxicological effects, with the uptake pathway being through the GI tract. Suggestion that further work involving uptake and pharmacokinetics of $U$ in animals is needed..

Cloutier Health Phys (1986) 50(6):775-780.

Measurement of levels of $\mathrm{Ra}-226$ in vegetation and bone of voles, and from this data the calculation of a transfer coefficient. Possible procedural paper for assessing $U$ transfer to small mammals.

Sullivan Health Phys (1986) 50(2):223-232.

Comparison of uptake in rats that were either fasted or feed ad libitum, and the effect of mild oxidizing or reducing agents on uptake. Fasted animals and mild oxidizing agents (ferric Fe and quinhydrone) increased uptake of all nuclides.

Simon and Fraley. J Environ Qual (1986) 15:345.

Looked at root uptake of $\mathrm{Ra}, \mathrm{Pb}, \mathrm{Po}$ to get CR's for each nuclide, as well as kinetics of distribution in leaves. Determined $\mathrm{Cr}$ values of 0.04 . 0.009, and 0.8 for $\mathrm{Ra}, \mathrm{Pb}$, and Po respectively.

LaTouche, Willis, Dawydiak. Health Phys (1987) 53(2):147-162.

Intensive study looking at the kinetics of GI uptake and distribution in the body of a uranium solution given by oral gavage. Bone was the primary deposition site, followed by kidney. Fasted animals demonstrated higher uptake levels.

Domingo Bull Environ Contam Toxicol (1987) 39:168. 
LD50 values were established for both oral and subcutaneous exposures for both rats and mice. Oral values were approximately $210 \mathrm{mg} / \mathrm{kg}$ whereas subcutaneous were 8 to $20 \mathrm{mg} / \mathrm{kg}$. Several chronic effects were documented for animals receiving single doses of uranium. The most important of these is thought to be kidney injury.

Silver. App Environ Microbiol (1987) 53:846.

Delineation of the distribution of the bacteria on the tailings site sought in order to correlate location of the bacteria to known sites of soluble iron and sulfates, as well as the effect of vegetation on bacteria activity. Conclusion that vegetation directly on the tailings did not arrest bacterial pyrite oxidation.

Burns Health Phys (1987) 52(2):207-211.

Use of prepared food in a controlled uptake study. Values of about $25 \mathrm{x}$ less than in above study explained by age-dependent bone differences. Additional factor may be the transfer from mother to offspring of $\mathrm{Ra}-226$.

Tbrahim and Whicker. Health Phys (1988) 54(4): 413-419.

Paper documenting the levels of uptake of various isotopes of $U$ and $T h$ by native vegetation at a mill tailings site in WY. Grasses, forbs and brush were collected and analyzed. Significant differences in the uptake of different Th isotopes were observed.

Lakshanan and Venkateswarlu. Water Air Soil Poll (1988) 38:151-155.

Experiment with uptake of $U$ from soil and from water, and the subsequent distribution in the plants. Fairly high CR's observed for the $U$ in water route.

Sheppard and Evenden. J Environ Radioact (1988) 8:255-285.

Review of analysis of available information on the uptake of $\mathrm{U}, \mathrm{Th}$, and $\mathrm{Pb}$. Authors were able to show that CR's significantly varied with soil type and plant species. CR values decreased as soil concentration increased.

Wong. Bull Environ Contam Toxicol (1988) 40:525.

Effect of uranyl nitrate on 398 strains of coliform bacteria was analyzed. At a concentration of $1 \mathrm{~g} / \mathrm{L}, \mathrm{UO}_{2}$ had no toxic effects on any of the strains.

Sela, Tel-Or, Fritz, Huttermann. Plant Physiol (1988) 88:30-36.

The tissue distribution and effect of $\mathrm{Cd}, \mathrm{Cu}$, and $\mathrm{U}$ was analyzed in the water fern Azolla, and its nitrogen-fixing symbiont Anabaena azollae. Documentation of accumulation within the cells and within the plant tissue was shown. Additionally, the effects of the metals (concentration $=10 \mathrm{ppm}$ ) on the ionic content of the plant were described. U increased $\mathrm{Ca}$ content and decreased $\mathrm{K}, \mathrm{Cl}$ and $\mathrm{Mg}$ in roots of Azolla. $U$ was located within the roots in the cytoplasm of epidermis cells, and in the tangential and radial cells of the parenchyma. Chollera concentrated $U$ in the cell wall $(95 \%)$. 
Cole. APG 38 (1989).

Evaluation of radiological and chemical health risk posed to personnel working around and using DU munitions. No relevance to ecological aspects with the exception of a discussion of the properties of DU itself. Summary of known human toxicological effects is given.

Linsalata . Health Phys (1989) 56(1):33-46.

Fairly extensive paper dealing with CR's of various $\mathrm{U}$ and $\mathrm{Pu}$ daughter products. General concern is human exposure routes through vegetable transfer.

Paternain Ecotox Environ Safety (1989) 17:291-296.

Paper dealing with effects of uranyl acetate dihydrate in Swiss mice.

Embryolethality observed at $25 \mathrm{mg} / \mathrm{kg} /$ day dose. Depressed growth observed at 5 , 10 , ands $25 \mathrm{mg} / \mathrm{kg} /$ day concentrations.

Leggett. Health Phys (1989) 57(3):365-383.

Extensive review of knowledge of physiology and pharmacokinetics of $U$ in the mammalian kidney.

Domingo Toxicol (1989) 55:143-152.

Controlled study with Swiss mice and uranyl acetate dihydrate. Both maternal toxicity and fetotoxicity were observed at concentrations of 5-50 ppm. A NOEL level was determined to be below 5 ppm. Mishima, Jette, Glissmeywer. APG 39 (1989).

Suggested that inhalation is most damaging acute pathway. Also a brief summary of national lab papers on use of DU.

Butnik and Ischenko. Agrokhimiya (1989) 11:80.

Field and pot experiments indicated that mineral fertilizers and/or manure application reduced uptake of $U$ and $T h$ by the plants. Manure + fertilizer had the greatest effect. Fertilizer application altered the bioavailability of the nuclides to the plants. Reduction factors of up to 3.8 were achieved.

Sheppard, Evenden, Pollock. Can J Soil Sci (1989) 69:751-767.

Controlled lysimeter study using four different soil types and several different agricultural plants with $\mathrm{U}, \mathrm{Th}$, and $\mathrm{Pb}$. Sand substrate demonstrated greatest uptake. $U$ only one of the nuclides to demonstrate soil concentration-dependent uptake.

Anan'yan. Agrokhimiya (1989) 10:100.

Small plot experiments on the $U$ content of hay. Fertilizers ( $P$ and $N$ ) increased grass yield and the accumulation of $U$. Phosphorus increased $U$ uptake by $34 \%$, whereas $\mathrm{N}$ application increased $\mathrm{U}$ uptake by $26 \%$. Uptake by the grasses was still 
only in the hundredths to thousandths off a percent in comparison to soil content.

Brown. pages 502-510 in Transfer of radionuclides in natural and semi-natural environments. eds:Desmet, Nassinbeni, Belli (1989) Elsevier Applied Science.

Uptake of Cs, S, Ru by Calluna and subsequent transfer to heather beetles was analyzed. Ultimate concern with the fate and cycling of radionuclides in a heath ecosystem.

Linsalata J Environ Radioact (1989) 10:115-140.

Measurement of the transfer of natural uranium from a site of background radioactivity to cattle. Determination of distribution within tissue and in regards to various food items. Suggestion that soil attached to or intermixed with forage items is likely the most important pathway for most of the elements.

Erikson PNL-7213/UC-602 (1990).

A review of the physical properties of DU munitions in the environment. Primary forms of DU after weathering are U (IV) and U (VI) oxides. Properties concerning the kinetics of oxidation are discussed. Solubility of different forms are mentioned. A final mention of factors influencing uptake by plants is given..

Ebinger LA-11790-MS/UC-000 (1990).

Work primarily focused on hydrologic and chemical transport of DU munitions at the two sites. Discussion of factors influencing migration into soil profile and offsite.

Aoyama, Honma, Kasai. Holzforschung (1991) 45:75.

Nineteen species of conifer leaves were studied to determine ability of these leaves to bioabsorb uranium from mining wastes and/or water.

Loveley Nature (1991) 350:413-416

Evidence that $\mathrm{Fe}(\mathrm{III})$-reducing microorganisims can obtain energy for growth by electron transport to U(VI). Uranium (VI) is the normal oxidized, soluble form of $\mathrm{U}$ in the environment. Microbial reduction to $\mathrm{U}(\mathrm{IV})$ reduces solubility.

Llobet Fund Appl Toxicol (1991) 16:821-829.

Concentrations of uranyl acetate dihydrate of $0-80 \mathrm{mg} / \mathrm{kg} /$ day were given to male Swiss mice in drinking waterfor 64 days. A significant decrease in pregnancy rate was observed for the $10-80 \mathrm{mg} / \mathrm{kg}$ doses, though the effect was not dose dependent. Body weight was significantly depressed at the $80 \mathrm{mg} / \mathrm{kg} /$ day dose. No alteration in physiological function was observed for any of the doses.

.Sheppard and Evendon. Arch Environ Contam Toxicol (1992) 23:117.

Uptake of uranium ranging in concentration from background to $10,000 \mathrm{mg} / \mathrm{kg}$ dry soil were studied using radish and beans, as well as accumulation in earthworms. 
Additionally, two different extraction methodologies were compared. Earthworms had BAF's ranging from 0.082 (organic) to 1.53 (acid sand). Beans and radishes demonstrated minor differences in uptake between soils, with CR's ranging from 0.013 to 0.237 .

Guibal, Roulph, Le Cloirec. Wat Res (1992) 26(8):1139.

Testing of fungal biomass as a remediation technique for $\mathrm{U}$ waste areas. Adsorption kinetics and capacity were analyzed. Determination that $\mathrm{pH}$ was quite important for biosorption.

Sheppard, Evendon, Anderson. Env Tox Water Qual (1992) 7:275-294.

Important paper dealing with phytotoxicity of uranium. Several different soils were used in the testing. Agricultural crops and pine were analyzed at both juvenile stages (germination and growth) and at maturity. Additional tests with earthworms, and phosphatase activity in soil were also performed. Authors concluded that there was no significant toxicity at levels below 300ppm. Significant toxicity observed at levels from $1000 \mathrm{ppm}$ to $10000 \mathrm{ppm}$.

Clulow Environ Pollution (1992) 77:39-50.

Documentation of levels of radionuclides in grouse, their preferred forage, and water. Emphasis on $\mathrm{Ra}$, but some measurement of $\mathrm{Po}, \mathrm{Pb}, \mathrm{U}$, and Th. Main purpose was to determine Cr's for the modeling of contaminant movement within the ecosystem. Several radium CR's were greater than unity for grouse. Uptake from water was particular strong.

Hossner, Woodard, Bush. J Plant Nutrition (1992) 15(12):2743.

Se and $U$ often found together in TX, prompts concern that forages on reclaimed $U$ mine lands may have high selenium levels. Ten grasses were compared from mine sites to a greenhouse control. Recommendation of Cynodon dactylon and Panicum coloratum for cover stabilization made. Observation that shoot weights were reduced in some of the species at the mine sites likely due to high Se levels.

Bosshard, Zimmerli, Schlatter. Chemosphere (1992) 24(3):309-321.

Study out of Switzerland concerning human risk assessment in regards to natural U. NOEL of $1 \mathrm{mg} \mathrm{U} / \mathrm{kg} /$ day suggested in terms of chemical toxicity. Detailed review of 'state-of-the-art' in regards to uptake, distribution, and excretion of $U$.

. Pettersson . J Environ Rad (1993) 19:85.

Australian waterlily looked at due to its use in the Aboriginal diet. Results demonstrated that sediment was the major route of uptake for these plants (vs water). CR's calculated were $0.01-0.03$ for roots and rhizomes and $0.005-0.015$ for foliage.

Liu and Wu. J Environ Sci Health (1993) A28(2):491.

Conditions for optimizing the uptake and subsequent recovery of nuclides from 
wastewater were analyzed. The best conditions allowed for $92 \% \mathrm{Am}$ and $85 \% \mathrm{U}$ uptake, and subsequent recovery of $46 \% \mathrm{Am}$ and $82 \%$ of the U originally in the wastewater.

. Fresquez, Armstrong, Salazar. LA-12795-MS (1994).

Short paper documenting levels of $\mathrm{U}, \mathrm{Cs}, \mathrm{Sr}$, and $\mathrm{Pu}$ in various tissues of elk. A comparison was made between elk living on LANL and those offsite. No statistically significant differences were observed. However, due to there being only 3 samples each for the treatment and control, power was definitely limited.

Domingo. J Tox Environ Health (1994) 42:123-41.

Several different toxicological experiments involving mice and uranyl acetate dihydrate(UAD) are described. Fetal toxicity was observed for gavage doses of 5$50 \mathrm{mg} / \mathrm{kg} / \mathrm{d}$. Overall, the work described is less than complete in terms of the tetragenicity of uranium.

Linsalata. J Env Qual (1994) 23:633.

A good review of exposure pathways and accumulation sites in agricultural food chains. Ultimate concern is human dose exposure regimes. Comparison of various food items in terms of percent of dietary dose of uranium and decay daughters. Decent list of references concerning uptake and effect studies (mostly human).

Cowart and Burnett. J Env Qual (1994) 23:651-662.

General discussion of decay series for $U$ and $T h$ including distribution in the environment and decay series pathways. Mention of speciation factors of both parent and daughter nuclides.

Mortvedt. J Env Qual (1994) 23:643-650.

Review of soil and plant factors in regards to nuclide bioavailability. Discussion of benefits and limitations of CR approach.

Nukleonica 1974 19(1):62-68 TK9001.N862 (Ra uptake)

J Geochem Exploration 1993 46(3):365 TN270.A1J68 (U prospecting using vegetation)

Science of the Total Env 1992 125:137-58 RA565.S365 (U toxicity in fish)

Rad Botany 1970 10:371 QK757.R3 (Po uptake by plants)

IAEA-SM-199/76 Vienna (1976). (U in soil profile at NV Test Site)

J Environ Qual 1994 23:630 (Overview of symposium papers)

$199423: 667(\mathrm{Ra}, \mathrm{Pb}$, Po transfer to cattle) 
1994 23:663 ( $\mathrm{Ra}, \mathrm{Pb}$, Po transfer to milk)

1994 23:671 (soil and amendments to soil, and Ra uptake)

Health Phys 1985 49(5):747 (food-chain transfer of U-series in aquatic env.)

$198140: 63$ (Pu transport in terrestrial ecosystems)

1975 29:583 (Pathways of Pu in plants and animals)

1985 49:239 (Alternative to pathway model)

BNL-51574/UC-70 (Microbial processes on radionuclide mobility)

Can J Bot 1984 62:1069-1075 (U uptake by plants over a low-grade ore body)

Sci Total Environ 1981 19:83-94 (Role of macrofungi in tailings re-vegetation)

NUREG/CR-2975/UCID-19463 1982 (Review of lit/procedures for soil-to-plant conc. factors).

UCRL-82545 1979 (Transfer factors for human dose pathway through ag products)

UCRL-81640 1979 (same as above) 


\section{Phytotoxicity of Depleted Uranium on Three Grasses Characteristic of Different Successional Stages.}

Michael Meyer, Bill Alldredge, and Terry McLendon.

Dept. of Fishery and Wildlife Biology, Center for Ecological Risk Assessment and Mgmt., Colorado State Univ., Ft. Collins, CO. 80523.

(Based on a poster given at SETAC 2nd World Conference, Vancouver, BC, Nov. 1995.)

\section{Abstract}

In response to a paucity of data on the chemical toxicity of uranium to plants, a factorial experiment employing five uranium concentrations $(0,50,500,5000,25000 \mathrm{ppm})$ and three moisture regimes (low, medium, high) was performed using three native grasses. Buchloe dactyloides (buffalograss- mid/late seral), Schizachyrium scoparium (little bluestem- late seral), and Aristida longiseta (purple threeawn- early/mid seral) were grown in monocultures and every mixture of two species under all combinations of uranium and moisture levels. This design allows for the analysis of uranium effects, as well as possible compound effects due to moisture stress. Several measures of plant health and viability were made, including: percent emergence, survivability of seedlings and mature plants, root and shoot biomass, and the number and mass of inflorescences. No significant differences between uranium levels were observed in terms of emergence and seedling survival. Effects are evident for plant biomass, fecundity, and long-term survivability

Key Words: phytotoxicity, depleted uranium, moisture stress, succession

\section{Introduction}

Understanding the effects of depleted uranium in the environment is a necessary element to providing a sound scientific basis for site management of numerous contaminated areas. These areas are a result of widespread testing and deployment of depleted uranium munitions throughout the world. Sheppard and colleagues have discussed the lack of data concerning uranium toxicity in plants, and the inconsistencies in the data that is available (Sheppard et al. 1992). Much of the literature available on phytotoxicity is rather anecdotal (Cannon 1952; Shacklette 1964), or concentrated on agricultural products, and radiological effects (Koul et al. 1983; Murthy et al. 1984; Sheppard et al. 1992). Espe- 
cially lacking is information on the chemical toxicity, and resulting ecological effects of depleted uranium (DU) on non-crop plants and on plant community structure.

In order to provide initial baseline values for these effects, a factorial experiment using 5 levels of depleted uranium $(0,50,500,5000$, and $25000 \mathrm{ppm})$, and three moisture levels (high, medium and low) tested over 6 plant combinations was designed. Three widely distributed range grass species were tested. Schizachyrium scoparium (little bluestem), Buchloe dactyloides (buffalograss), and Aristida longiseta (red threeawn) were grown in monocultures and every combination of two of the three species. Schizachyrium is a late seral grass of a more mesic character, whereas Buchloe is a mid/late-successional grass found in arid sites. Aristida is an earlier seral grass that is xeric in nature. Several measures of plant viability and health were taken in order to assess plant response to the two stressors of uranium and drought. Long-term survivability, fecundity and biomass were significantly effected by these stresses.

\section{Materials and Methods}

Greenhouse: A completely randomized full factorial design was used, and can be seen in Figure 1. Schizachyrium scoparium, Buchloe dactyloides, and Aristida longiseta were grown from seed acquired from Granite Seed (Lehi, UT) in 4 inch square by 14 inch deep plastic pots from Stuewe and Sons, Inc. (Portland, OR). Pots were randomly allocated to 18 rows on two tables in a greenhouse. Artificial lighting maintained a 16 hour light/ dark schedule. Temperature was allowed to fluctuate from 20 to $30 \mathrm{C}$. Growth substrate was locally supplied sand supplemented with Osmocote 120-day slow release 14-14-14 fertilizer applied at a rate of $2 \mathrm{oz}$ per cubic foot. Depleted uranium was supplied as weathered material collected from deployed munitions at the Yuma Proving Grounds in Arizona, and is in the chemical form of schoepite (UO2(OH)2-nH2O). This material was ground using a mortar and pestle and distributed into soils at the following concentrations: $0,50,500$, 5000 , and $25,000 \mathrm{ppm}$. Only the top $6 \mathrm{~cm}$ of each pot was treated with the uraniumspiked sand. Initially, 12 seeds were placed in each pot, either all of one species, or 6 of each of two different species. Water was applied ad libitum. Emergence success was measured as the percentage of seeds that produced visible seedlings at day 10 . Successive measurements were made at day 17 and day 24 to assess seedling survival.

Results

Tukeys HSD was used to determine group differences in all tests. If ANOVA assumptions did not hold, then the Wilcoxon rank sum non-parametric alternative was used. Plant mortality was assessed using loglinear analysis. Treatment groups were compared using linear contrasts. 
There were no significant differences in seeding energence between uranium levels, based on a Tukey's test at $\mathrm{p}=0.05$ (Figure 2). No significant differences were observed for postseedling survival at day 17 nor day 24 .

Aboveground biomass estimates for each of the three species were pooled by pot(Figure 3). Differences are apparent only for the $25000 \mathrm{ppm}$ level of uranium. Stolon number for Buchloe was reduced only at the $25000 \mathrm{ppm}$ level as well (Figure 4).

Inflorescence number and mass (Figures 5 and 6) were analyzed using ANOVA. Schizachyrium did not produce inflorescences over the period of the study. Buchloe and Aristida showed significant differences in mass and number of inflorescences at the $25000 \mathrm{ppm}$ level.

\section{Conclusions}

- Depleted uranium does not effect grass emergence at levels up to $25,000 \mathrm{ppm}$

- Overall, a threshold response to uranium is observed in terms of biomass and fecundity measures, with effects only seen at levels above $5000 \mathrm{ppm}$

- Differences are seen between species in the measures of post-seedling survival, aboveground biomass, and fecundity.

- Schizachyrium failed to send out inflorescences, whereas over $70 \%$ of Aristida plants had at least one inflorescence. This may be a result of life history or experiment duration rather than uranium effects.

- Water was a significant predictor in most of the ANOVA models. The interaction of water and uranium, however, was never significant. This suggests that drought stress and uranium stress are independent.

\section{References:}

Cannon, H.L. (1952) The effect of uranium-vanadium deposits on the vegetation of theColorado Plateau. Am. J. Science 250: 735-770.

Koul, S.L., Kaul, V., Chadderton, L.T. (1983) Uranium uptake and the cytology of Cyclanthera pedata: a fission track study. Environ. Expt. Botany 23(4): 379-392.

Murthy, T.C.S., Weinberger, P., Measures, M.P. (1984) Uranium effects on the growth of soybean. Bull. Environ. Contam. Toxicol. 32:580-586.

Shacklette, H.T. (1964) Flower variation of Epilobium angustiflium L. growing over uranium deposits. Can. Field-Naturalist 78:32-42.

Sheppard, S.C., Evendon, W.G., Anderson, A.J. (1992) Multiple assays of uranium toxicity in soil. Environ. Toxicol. Water Qual. 7:275-294. 
Figure 1

\section{Plant Mortality}

[DU]

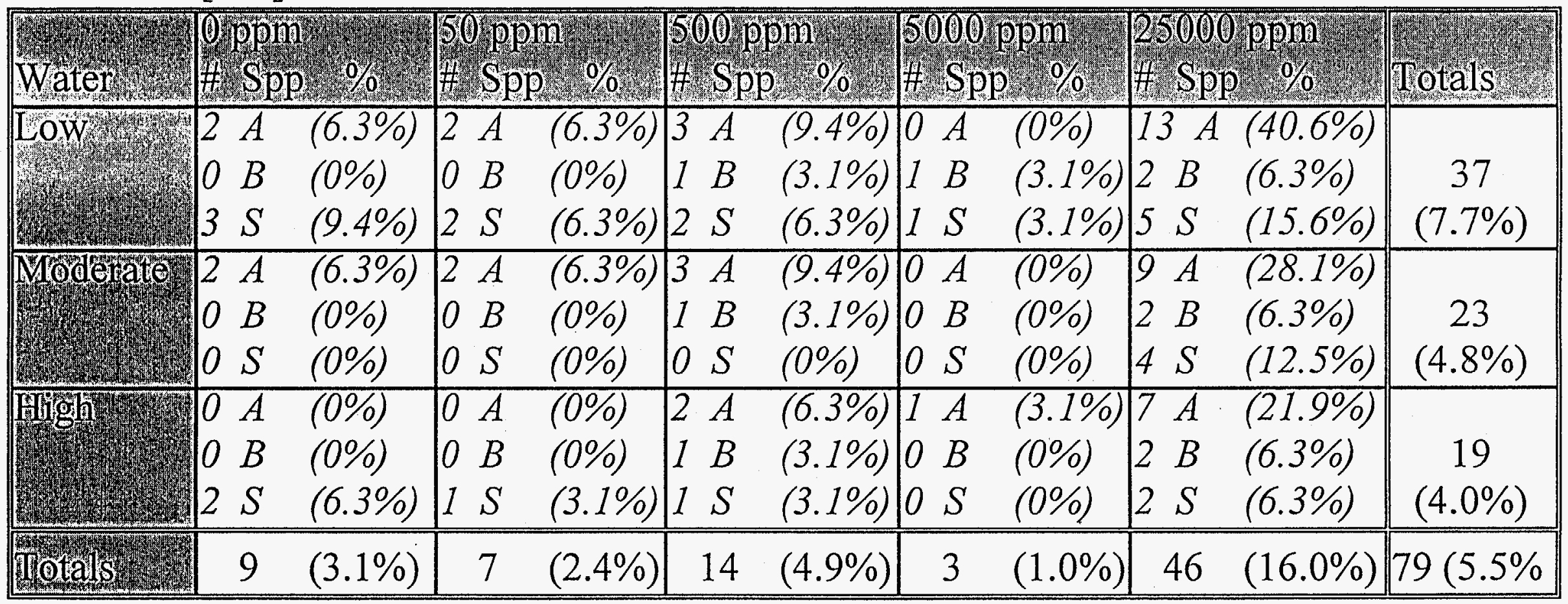

Plant mortality is broken out by species, uranium concentration, and water level. Mortality of the 25,000 grouping is significantly different from the others $(p<0.0001)$. Mortality is significantly different between species as well $(p<0.05)$. In terms of moisture, the high moisture is different from the low $(p=0.03)$, all other pairs are not significantly different. 
Figure 2

Emergence at Day 10

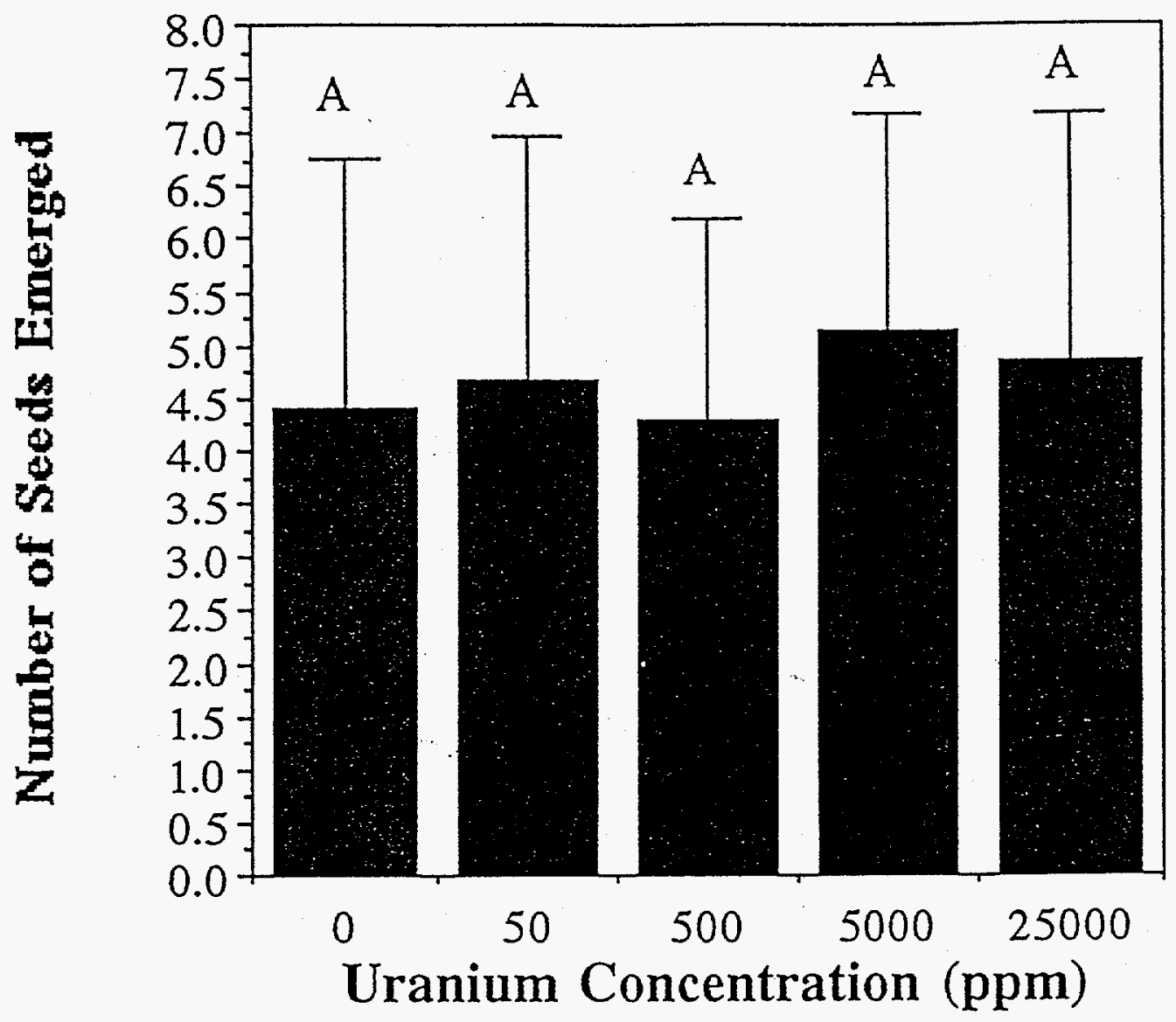

There was no observed significant differences between uranium levels for seedling emergence. Letters above the bars indicate Tukey's groupings at the 0.05 level. No differences were observed for post-emergence seedling survival at day 17 or day 24 either (data not shown). 
Figure 3

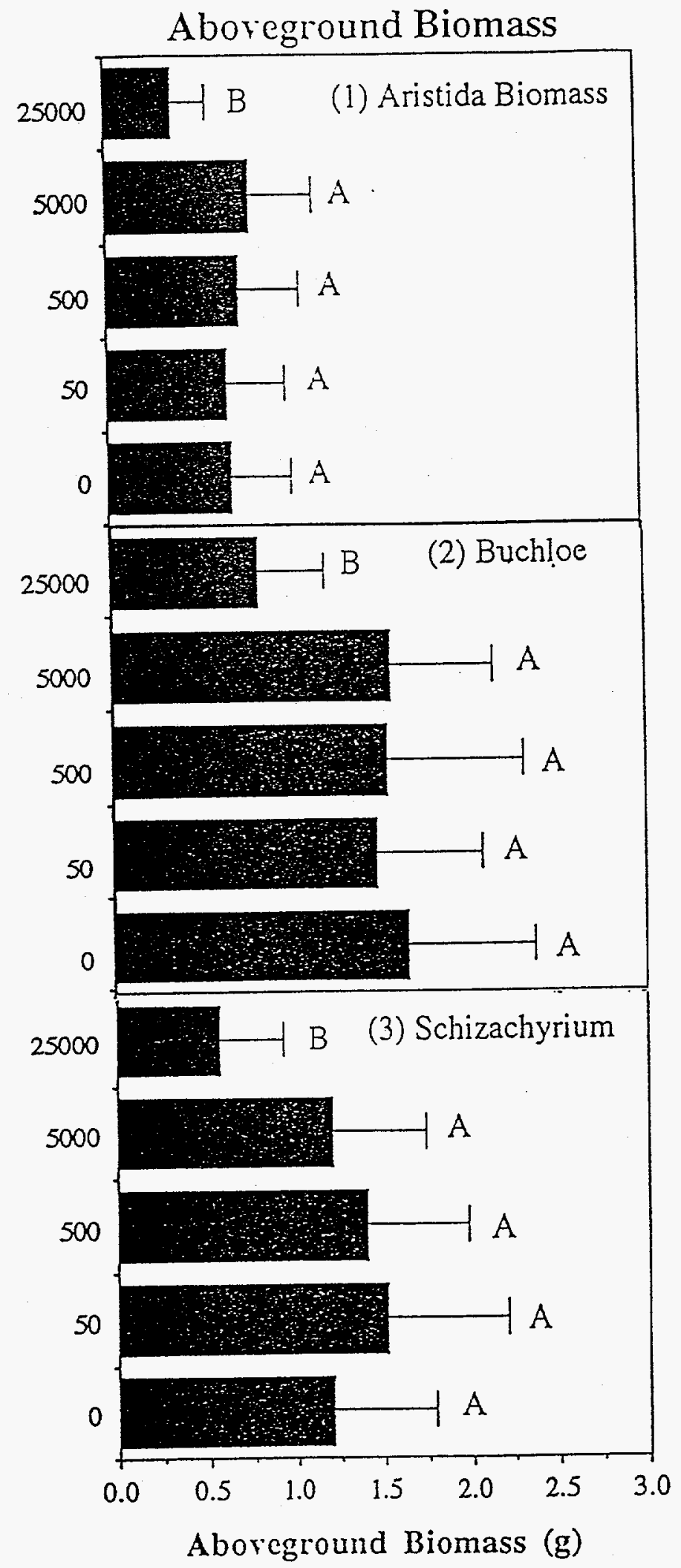

Graphs 1, 2 and 3 show the aboveground biomass for Aristida, Buchloe, and Schizachyrium. Values are for the pooled average of that species in each pot. Letters at the end of the bars represent Tukey's groupings at the 0.05 level, and are specific to each species. 
Figure 4

Number of Buchloe Stolons

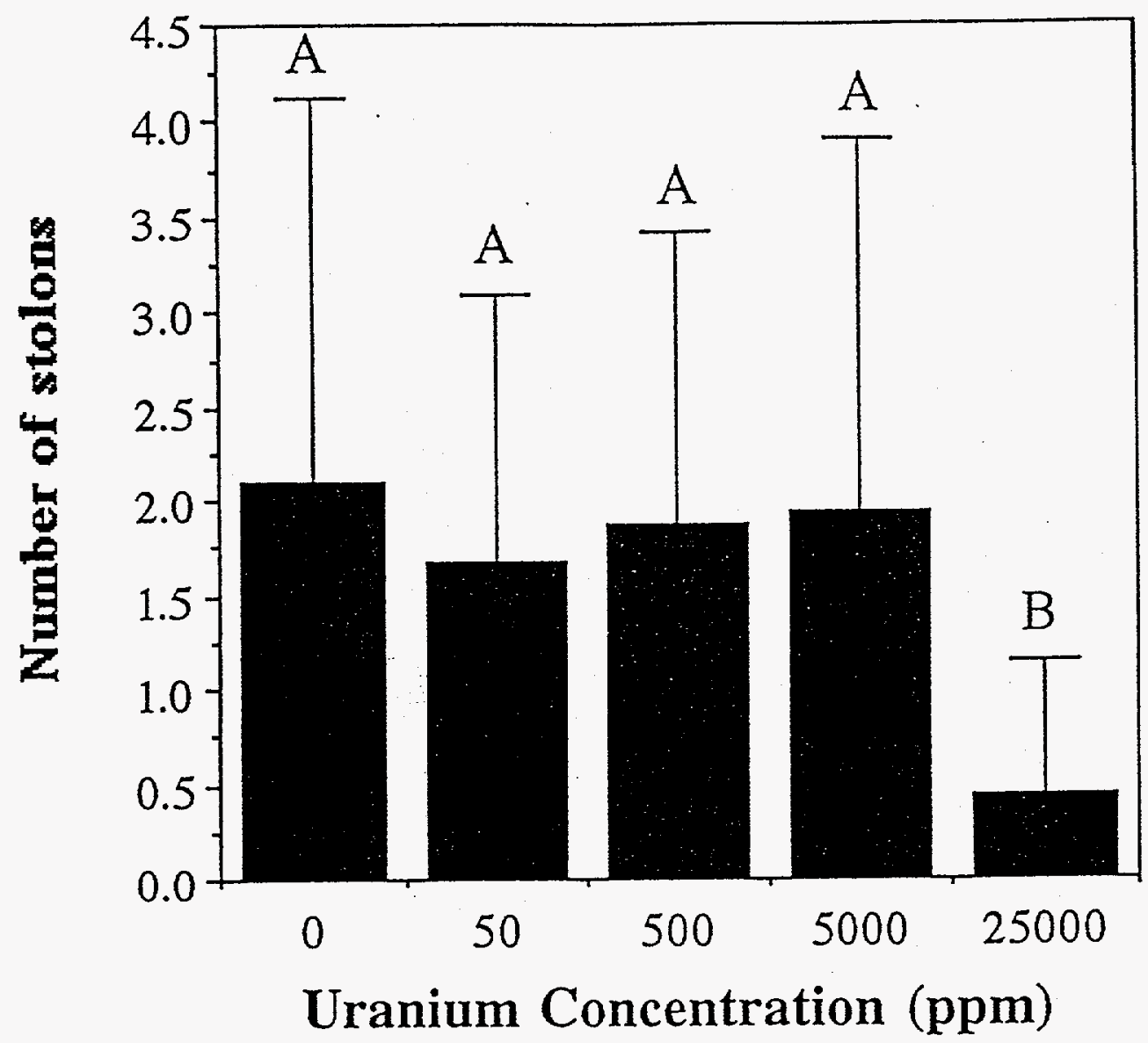

Shown is the number of Buchloe stolons observed at each uranium concentration. Values are for the pooled average of plants in each pot. Letters above the bars indicate Tukey's groupings at the 0.05 level. 
Figure 5

(A) Weight of Buchloe Inflorescences

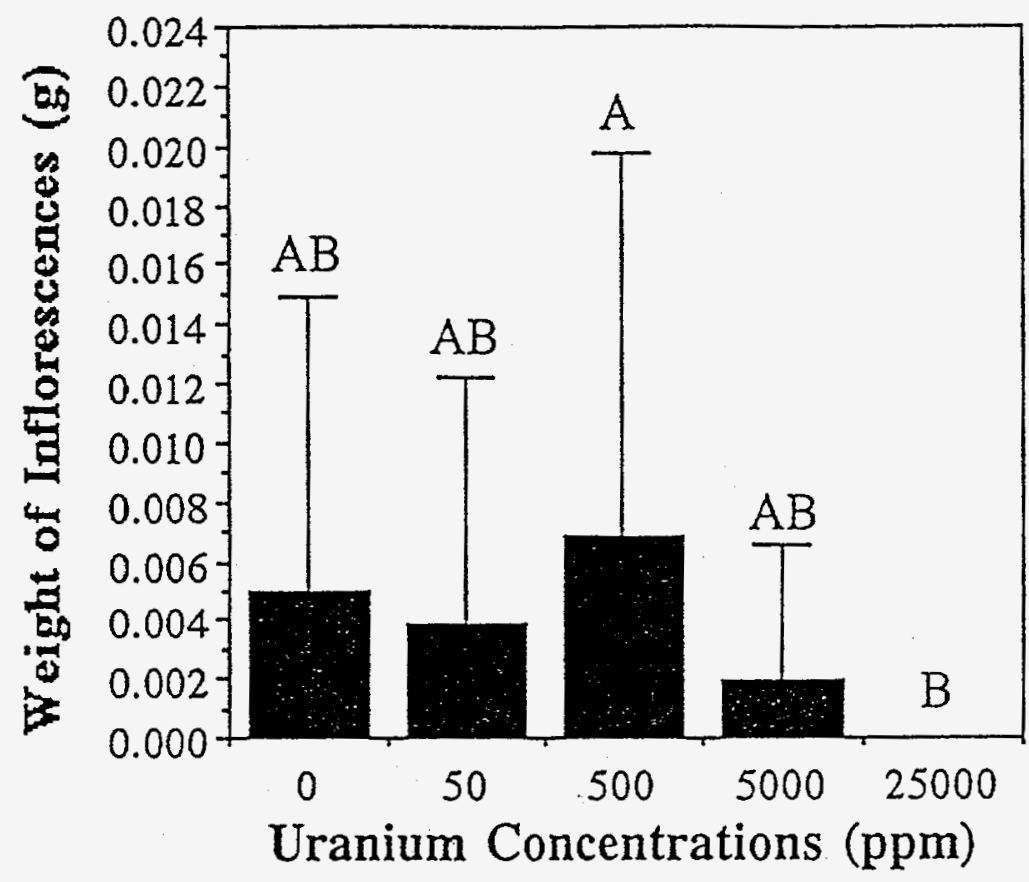

(B) Number of Buchloe Inflorescences

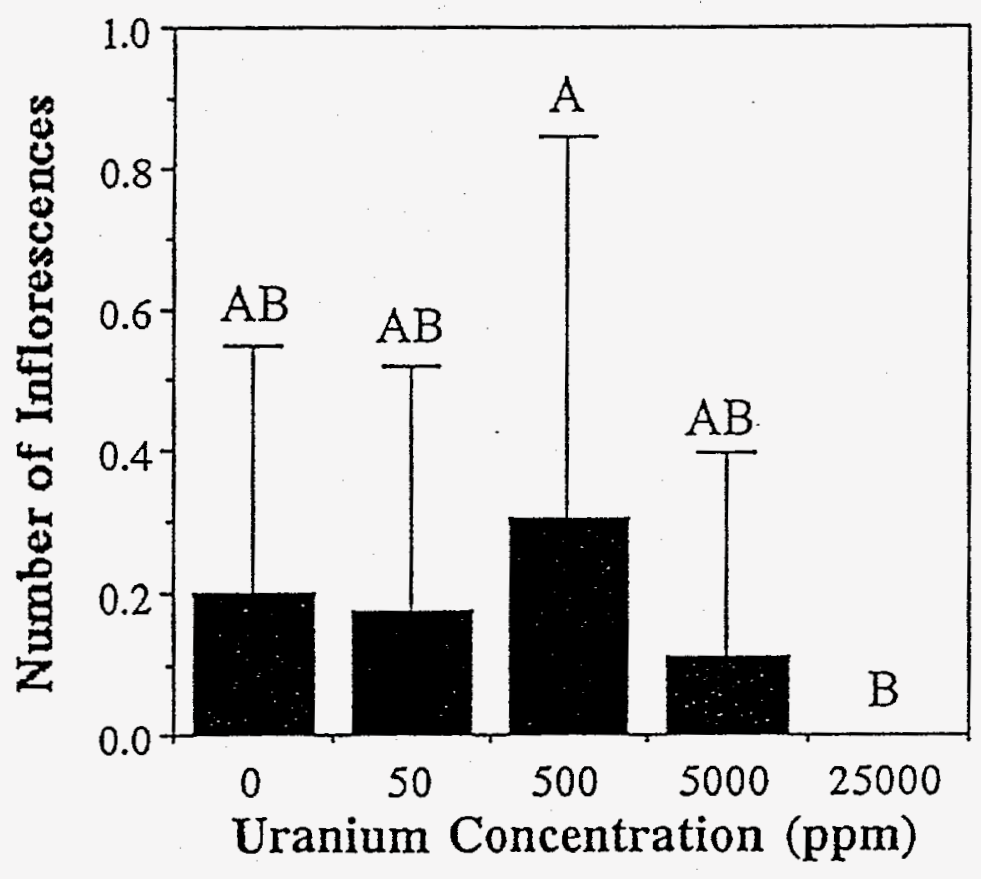

Graph A shows the weight of Buchloe inflorescences. Values are for the pooled average of plants in each pot. Letters above the bars indicate Tukey's groupings at the 0.05 level.

- Graph B is as above except it shows number of inflorescences produced. No inflorescences were produced under the 25,000 uranium treatment. 
Figure 6

(A) Weight of Aristida Inflorescences

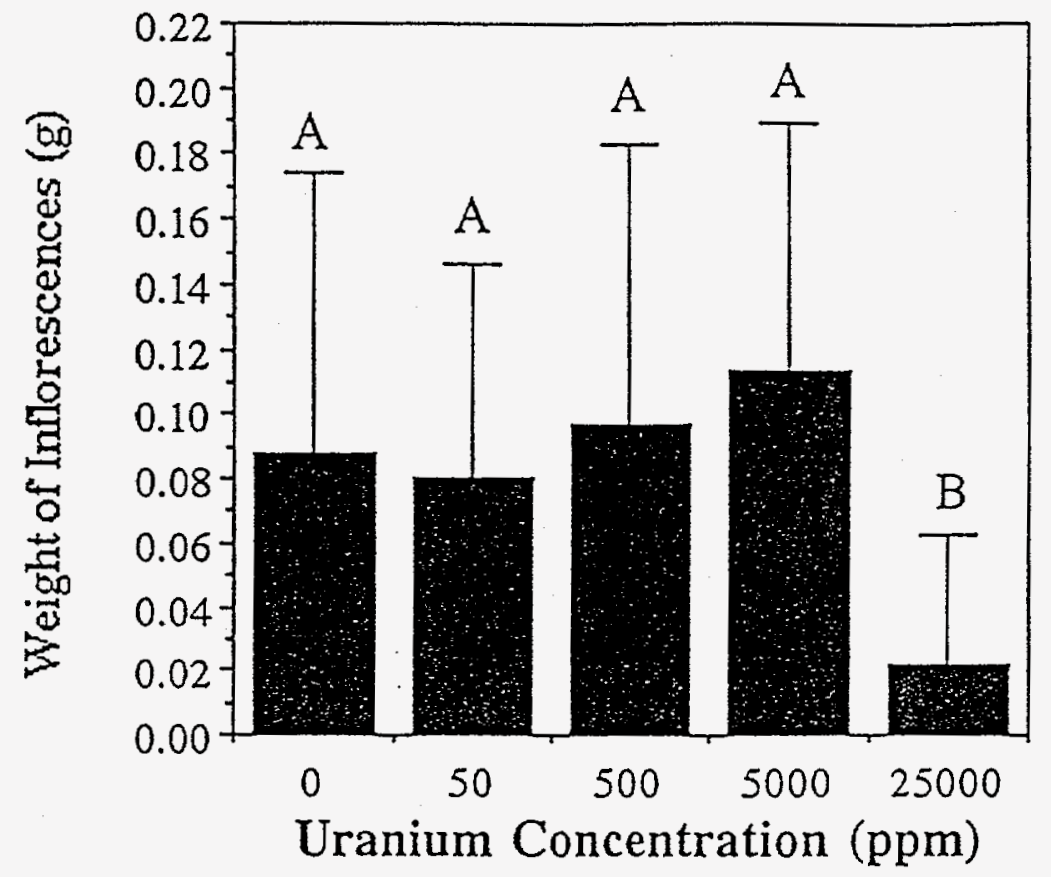

(B) Number of Aristida Inflorescences

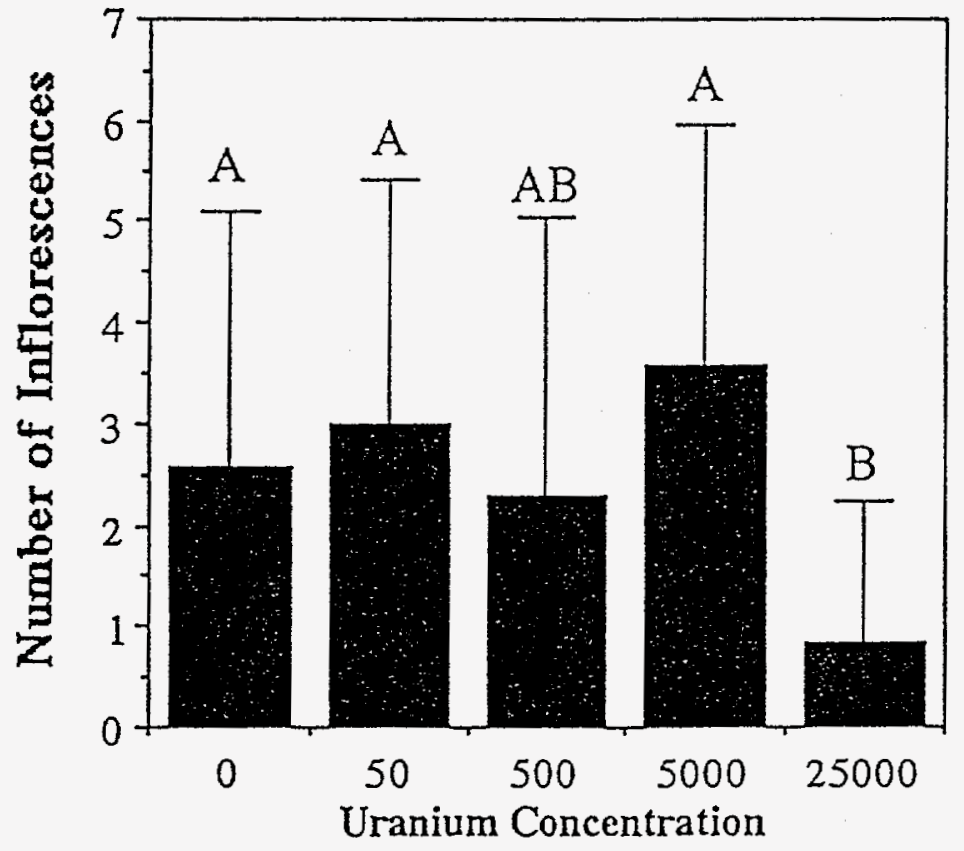

Graph A shows the weight of Aristida inflorescences. Values are for the pooled average of plants in each pot. Letters above the bars indicate Tukey's groupings at the 0.05 level.

Graph B is as above except it shows number of inflorescences produced. 


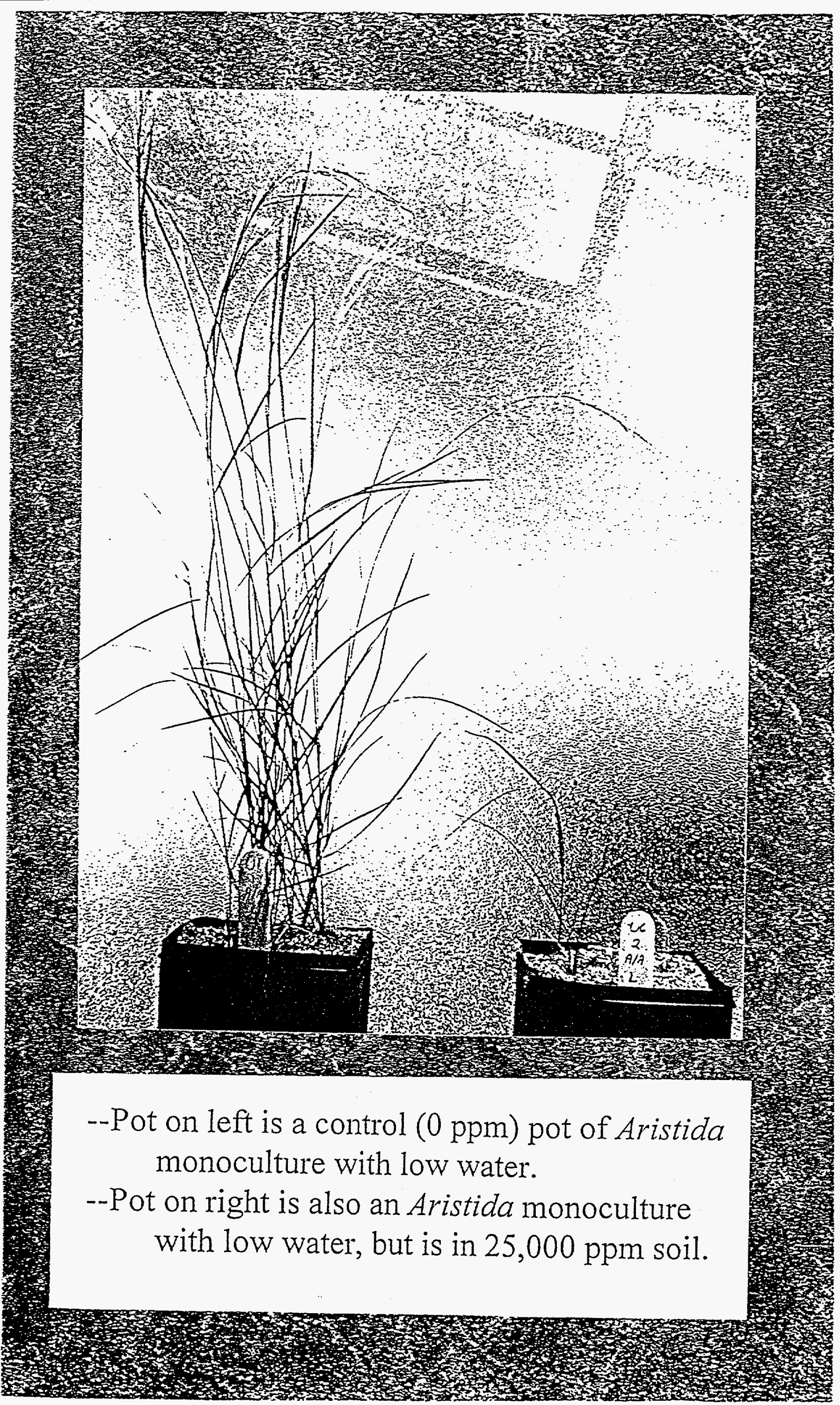




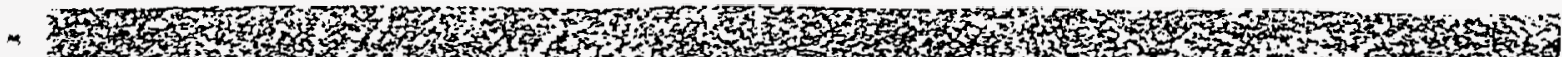

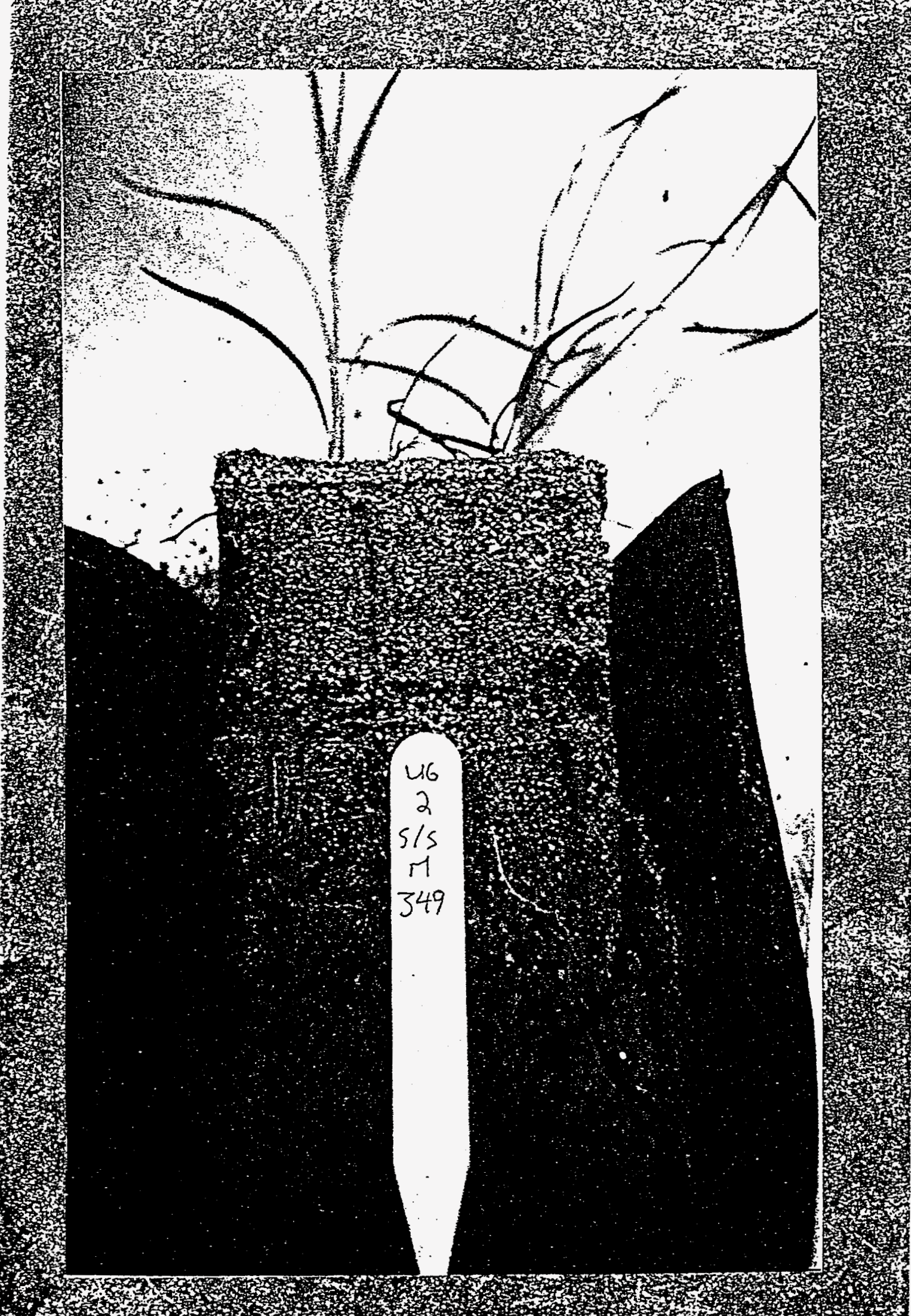
pot. Notice the top $6 \mathrm{~cm}$ yellow-specked layer of contamination. 